\title{
The British species of Enicospilus (Hymenoptera: Ichneumonidae: Ophioninae)
}

\author{
Gavin R. BROAD ${ }^{1, *} \&$ Mark R. SHAW ${ }^{2}$ \\ ${ }^{1}$ Dept. of Life Sciences, the Natural History Museum, Cromwell Road, London SW7 5BD, \\ United Kingdom. \\ ${ }^{2}$ National Museums of Scotland, Chambers Street, Edinburgh EH1 1JF, United Kingdom. \\ *Corresponding author: g.broad@nhm.ac.uk \\ ${ }^{2}$ E-mail: markshaw@xenarcha.com \\ ${ }^{1}$ urn:Isid:zoobank.org:author:D06689DE-526F-4CFA-8BEB-9FB38850754A \\ ${ }^{2}$ urn:1sid:zoobank.org:author:EBB32AF8-6A45-4AB9-8131-24812F916E99
}

\begin{abstract}
The nine British and Irish species of Enicospilus are revised, mapped and an identification key provided. One species, Enicospilus myricae sp. nov., is described as new; Enicospilus merdarius (Gravenhorst, 1829) is a senior synonym of E. tournieri (Vollenhoven, 1879) syn. nov.; the only available name for E. merdarius auctt. is Enicospilus adustus (Haller, 1885) stat. rev., and a neotype is designated for Ophion adustus Haller, 1885. Enicospilus cerebrator Aubert, 1969 and E. repentinus (Holmgren, $1860)$ are newly recorded from Britain. Some host data are available for eight of the nine species.
\end{abstract}

Key words. Taxonomy, parasitoid, nocturnal, host, new species.

Broad G.R. \& Shaw M.R. 2016. The British species of Enicospilus (Hymenoptera: Ichneumonidae: Ophioninae). European Journal of Taxonomy 187: 1-31. http://dx.doi.org/10.5852/ejt.2016.187

\section{Introduction}

Enicospilus Stephens, 1835 is a distinctive genus of primarily nocturnal parasitoids of relatively large Lepidoptera larvae. The genus is immensely species-rich in the tropics (Gauld \& Mitchell 1978, 1981; Gauld 1988) but only small numbers of species are found in north temperate regions. However, despite the small number of species in Britain (only five were listed by Fitton et al. 1978), there has been much confusion over the limits and identities of these species. Under the auspices of the first author's nocturnal Ichneumonoidea recording scheme (http://nocturnalichs.myspecies.info/), we have gathered host, distribution and phenology data on the British Enicospilus species and clarified some taxonomic issues. Considering the size of the fauna, now increased to nine species, the taxonomic problems were surprisingly extensive; these issues are summarised in the "Taxonomy of British Enicospilus" section below.

In Europe, Enicospilus species are easily recognised as the only Ophioninae with strongly narrowed mandibles, a large glabrous patch in the fore wing discosubmarginal cell (frequently with detached sclerites) and fore wing vein $R s+2 r$ partly thickened (see Fig. 1). Stauropoctonus bombycivorus 
(Gravenhorst, 1829), which might be confused with Enicospilus because they share twisted mandibles, lacks the occipital carina and has fore wing vein $R s+2 r$ abruptly angled near its origin on the pterostigma, in both respects unlike Enicospilus. Ophioninae can be recognised by the discosubmarginal cell extending beyond fore wing vein $2 \mathrm{~m}-\mathrm{cu}$ and the presence of a dark line (a "spurious vein") ventrally in the fore wing anal cell (Fig. 1). In common with many other nocturnal ichneumonoids, they are large (or very large), almost always mostly testaceous, with large eyes and ocelli, and long antennae.

Hosts of the British Enicospilus fall into two categories: Lasiocampidae, in the case of the very large E. inflexus (Ratzeburg, 1844) and E. undulatus (Gravenhorst, 1829), and low-feeding noctuids for the remaining species (although E. repentinus (Holmgren, 1860) has not been reared). As with most Ophioninae that have been reared, the host is probably attacked as a late instar larva, and habitually killed as it prepares to pupate; however, few details of the biology of British Enicospilus have been studied. All but one British species seem to be univoltine, with rather narrow periods of flight activity. There are too few data to establish the limits of host ranges, but at least two species (E. merdarius (Gravenhorst, 1829 ) and E. undulatus) have very restricted host ranges that may reflect limited diversity of hosts in their particular habitats. Habitat specialisation may be important in limiting distribution, rather than absolute host taxon specificity. For example, E. myricae sp. nov. has only been collected in Myrica Linnaeus, 1753 bogs and wet woodland, where it has been reared from a common and widespread host caterpillar which is present in a range of habitats. Interestingly, females of all British species (at least, those with good sample sizes) far outnumber males in light trap samples, whereas both sexes are reared

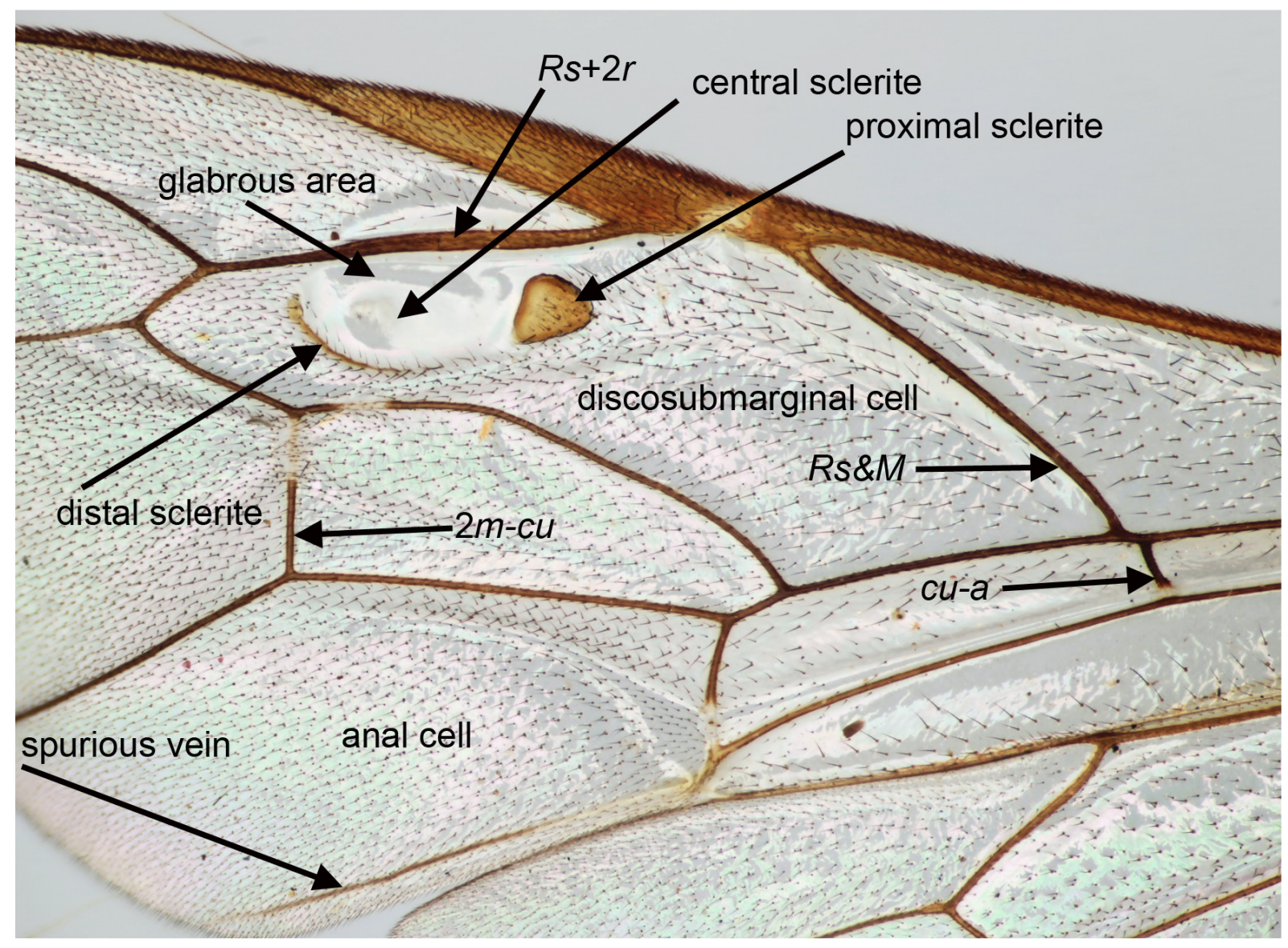

Fig. 1. Fore wing of Enicospilus merdarius (Gravenhorst, 1829) with sclerites, veins and cells referred to in the text labelled. 
in approximately equal numbers. While this might largely reflect the difference in longevity between the sexes, males may also be rather less nocturnal, as is certainly the case with some other ophionines, such as Eremotylus marginatus (Jurine, 1807) and Ophion ventricosus (Gravenhorst, 1829), males of which can be collected flying around trees in the daytime, whereas females are more strictly nocturnal (pers. obs.), although in these two cases the species are partly patterned with black.

\section{Material and methods}

The distribution maps for Britain and Ireland are based on far more records than any preceding maps dealing with the British parasitoid fauna; nevertheless, the ranges shown are very incomplete and suffer from several sources of recording bias. Hopefully these maps, which illustrate broad patterns of distribution, will encourage entomologists to record Enicospilus species in the many blank areas, so that eventually it will be possible to map changes in distributions over time. Maps were plotted using DMAP, developed by Alan Morton (www.dmap.co.uk). The main sources of specimen data are the collections of the Natural History Museum, London (BMNH), and the National Museums of Scotland, Edinburgh (NMS). These collections have been considerably enriched in recent years by donations from many entomologists, particularly moth trappers who have kindly sent their ichneumonoid catches to us. For the geographic spread of their light trap network, the Rothamsted light trap survey (see Woiwod \& Harrington 1994; Harrington \& Woiwod 2007) was a particularly important source of specimens; we include records from Rothamsted light traps on the Channel Islands, although these are not faunistically a part of Britain. We have also seen specimens from several private collections as well as the collections of British Entomological and Natural History Society, World Museum Liverpool and Cambrige University Museum of Zoology. Following other papers cataloguing the collections of NMS (e.g. Schwarz \& Shaw 1998, which explains the rationale), we give the numbers of specimens present in NMS (and BMNH in this case) and list the Vice Counties from which they have been recorded (from all data), as well as cataloguing non-British material in NMS. The full British dataset is available via the National Biodiversity Network Gateway (https://data.nbn.org.uk/), the full dataset via the Natural History Museum's Data Portal (http://data.nhm.ac.uk/) and in Supplementary File. "Unsexed" usually refers to specimens which now lack the metasoma.

Morphological terminology follows Gauld $(1988,1991)$. Sclerites and some wing veins and cells are labelled on Fig. 1; wing length is measured as the greatest distance from the apex of the tegula to the wing tip. Gauld \& Mitchell $(1978,1981)$ and Gauld (1988) employ several wing venation indices but, as these are uninformative in distinguishing closely related British species, they are not detailed here. We include ranges of number of flagellar segments, based on British specimens, rather than the total antennal segments, i.e. we exclude the scape and pedicel from the counts. Photographs were taken using a Canon EOS 450D digital camera attached to a Leica MZ12, with images stacked using Helicon Focus. Whole insect photos were taken by Harry Taylor at the BMNH.

\section{Collection abbreviations}

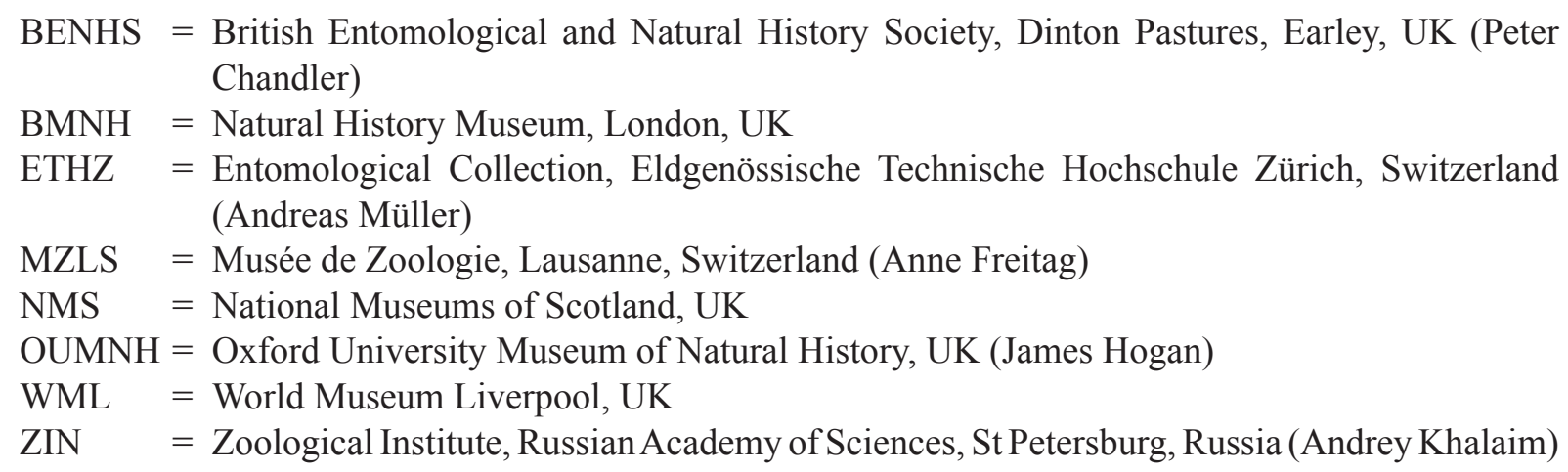




\title{
Results
}

\author{
Class Hexapoda Blainville, 1816 \\ Order Hymenoptera Linnaeus, 1758 \\ Superfamily Ichneumonoidea Latreille, 1802 \\ Family Ichneumonidae Latreille, 1802 \\ Subfamily Ophioninae Shuckard, 1840
}

Genus Enicospilus Stephens, 1835

\section{Taxonomy of British Enicospilus}

There have been no identification keys to British Enicospilus since Gauld's (1973) key and update (Gauld 1974). Unfortunately, these works contained significant misidentifications and lumped some species together. This is not surprising, as Gauld had access to rather small sample sizes and relied heavily on the number and shape of fore wing sclerites, which are of great use in Enicospilus taxonomy but are, unfortunately, almost identical in five of the British species. There has never been a thorough revision of European Enicospilus species, which is reflected in some frequent misunderstandings regarding species names and limits, although Viktorov's (1957) key is very useful. In Britain, Enicospilus can be divided into three species-groups, based on the sclerites in the fore wing discosubmarginal cell: E. inflexus and E. undulatus entirely lack sclerites (and have been referred to the genus Allocamptus Förster, 1869 by some authors); E. merdarius (= Ophion tournieri Vollenhoven, 1879) and E. repentinus have a welldefined proximal sclerite, with the central sclerite either absent or transparent; and the remaining five species (the ramidulus species-group) have both the proximal and central sclerites pigmented. There has been confusion in each of these species-groups, although it is within the ramidulus complex that species are most morphogically similar and hence have been persistently confused.

Gauld (1974) separated the very similar E. inflexus (Ratzeburg, 1844) and E. undulatus (Gravenhorst, 1829), that he had previously (Gauld 1973) confounded under the name E. undulatus; and Viktorov (1957) had already separated E. repentinus and E. tournieri (but see below), which Gauld (1973) had confused by identifying British specimens of E. merdarius (= tournieri) as E. repentinus, whereas the true E. repentinus had not been found in Britain at that time.

Most authors have recognised E. merdarius auctt. (but see below) as a separate species from E. ramidulus (Linnaeus, 1758). Although Gauld (1973) stated that there are specimens intermediate between E. merdarius auctt. and E. ramidulus, and treated them as synonymous, we have seen no such specimens, and Gauld \& Mitchell (1981) subsequently recognised the two as separate species. Differences in opinion regarding the status of E. merdarius auctt. and E. ramidulus have arisen because, although $E$. ramidulus has a distinctive identifying feature in the black-tipped metasoma, E. merdarius auctt. has no distinctive features, which we now know is because it is in fact a complex of similar species. Aubert (1966) had already separated off E. cerebrator Aubert, 1966, a species subsequently recognised in several European countries but never sought in Britain. We have found E. cerebrator to be widespread in Britain and also discovered a third species in this complex, which had no name, described here as E. myricae sp. nov. The identity of E. merdarius has been ignored since Fitton (1984) designated a lectotype; both before and after Fitton's (1984) lectotype designation, the name E. merdarius has frequently been applied to any Palaearctic Enicospilus with two discrete fore wing sclerites and lacking either a dark tip to the metasoma or dark patches on the mesosoma (i.e., excluding E. ramidulus and E. combustus (Gravenhorst, 1829)). Unfortunately, the lectotype of Ophion merdarius Gravenhorst, 1829 is the species that has generally been called E. tournieri, with the result that literature citations for E. merdarius do not refer to the species properly called E. merdarius (quite apart from the many misidentifications). Remarkably, for such a widespread species, there is only one potential synonym of 
E. merdarius auctt. (i.e., the larger species in the complex that includes E. cerebrator and E. myricae sp. nov.), namely Ophion adustus Haller, 1885, synonymised under E. merdarius by Horstmann (1997) on the basis of the brief original description, which could equally refer to E. cerebrator or E. myricae sp. nov. The type specimen(s) of $O$. adustus cannot be found so, to stabilise usage of the name, we designate a neotype for $O$. adustus, meaning that the widespread, large species, usually referred to as Enicospilus merdarius, should be called Enicospilus adustus. Allowing for his misconception of E. merdarius, this is in line with the synonymy proposed by Horstmann (1997).

\section{Identification key to British and Irish species of Enicospilus}

1. Fore wing lacking sclerites in glabrous area of discosubmarginal cell (Fig. 2A); large species, wing length $c .20 \mathrm{~mm}$...

- Fore wing with at least one discrete sclerite in discosubmarginal cell (Fig. 2B-D); smaller species, wing length $<15 \mathrm{~mm}$.

2. Head posteriorly, in dorsal view, not expanded laterally beyond the eyes; ocelli touching or almost touching eye; antennal socket separated from inner margin of eye by not more than a third socket diameter (Fig. 3A)

Enicospilus inflexus (Ratzeburg, 1844)

- Head posteriorly, in dorsal view, expanded so that head is wider than its width at the eyes; ocelli distinctly separated from eye by about $0.2 \times$ diameter of ocellus; antennal socket separated from inner margin of eye by about half socket diameter (Fig. 3B).....

Enicospilus undulatus (Gravenhorst, 1829)
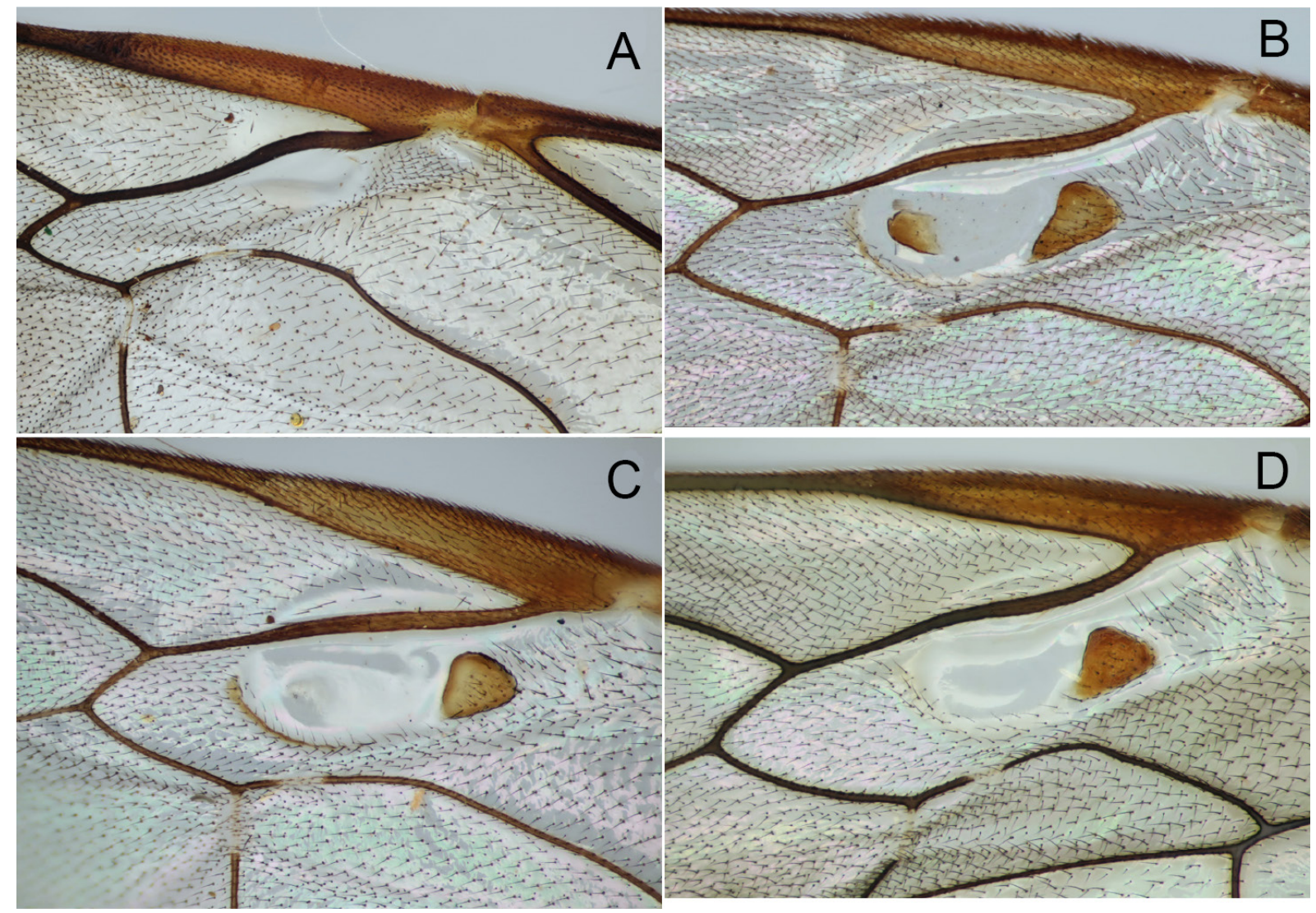

Fig. 2. Fore wing discosubmarginal cell. A. Enicospilus undulatus (Gravenhorst, 1829). B. E. ramidulus (Linnaeus, 1758). C. E. merdarius (Gravenhorst, 1829). D. E. repentinus (Holmgren, 1860). 
3. Fore wing with distinct, pigmented proximal and central sclerites (Fig. 2B)

- Fore wing with distinct, pigmented proximal sclerite: central sclerite may be present but translucent (Fig. 2C-D).

4. Pronotum, mesopleuron, mesoscutum and propodeum with dark patches (Fig. 14A).....

- Mesosoma lacking dark patches, uniformly testaceous.

Enicospilus combustus (Gravenhorst, 1829)

5. Metasoma abruptly tipped with black posteriorly, from $5^{\text {th }}$ or $6^{\text {th }}$ tergite (Fig. 14B)

Enicospilus ramidulus (Linnaeus, 1758)

- Metasoma not abruptly black-tipped (but may be diffusely infuscate ventrally and apically)......

6. Head with temples rounded, more buccate, and with distinct ocular-ocellar space (Fig. 4C); first metasomal tergite in lateral view with better-defined dorsal dip (Fig. 6C); male aedeagus apically paler, apex more rounded, protruding more dorsally and not reflexed ventrally (Fig. 9B)

Enicospilus myricae sp. nov.

- Head with temples narrowed, straighter, with ocelli adjacent to or only narrowly separated from eyes (Fig. 4A-B); first metasomal tergite with shallow dorsal dip (Fig. 6A-B); male aedeagus same colour throughout, apex more smoothly curved, not so protruding dorsally, reflexed ventrally (Fig. 9A) .. 7

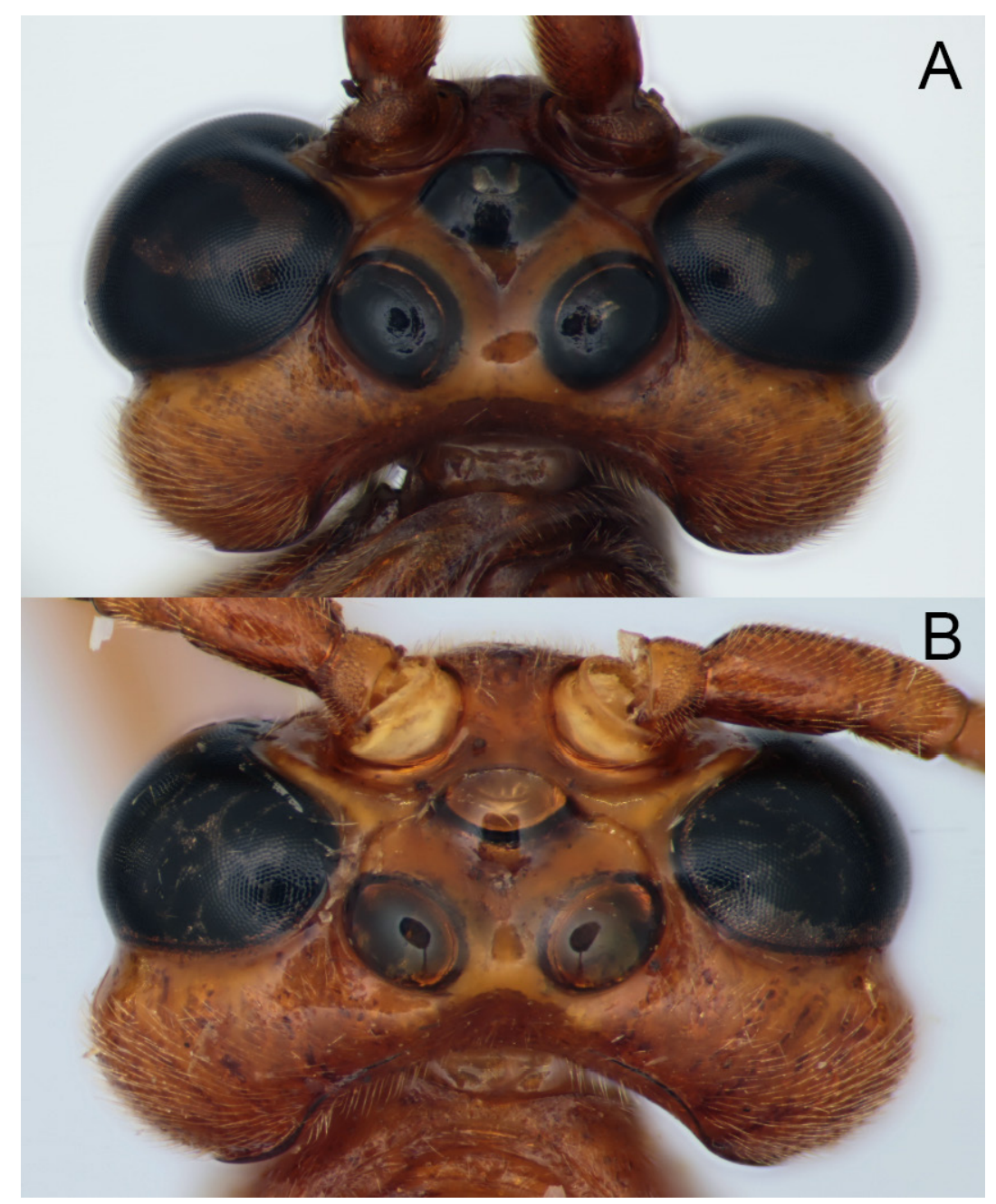

Fig. 3. Head, dorsal view. A. Enicospilus inflexus (Ratzeburg, 1844). B. E. undulatus (Gravenhorst, 1829). 
7. Temples very strongly narrowed behind eyes (Fig. 4A); scutellum with sides more nearly parallel, heavily punctate and with slight posterior ridge (Fig. 5A); antenna with 51-56 flagellar segments, preapical flagellar segments stouter (Fig. 7B)

Enicospilus cerebrator Aubert, 1966

- Temples less strongly narrowed posteriorly (Fig. 4B); scutellum with sides distinctly converging posteriorly, more sparsely punctate and smoothly curved posteriorly (Fig. 5B); antenna with 58-69 flagellar segments, preapical flagellar segments slenderer (Fig. 7A)

Enicospilus adustus (Haller, 1885) stat. rev.

8. Fore wing with small translucent central sclerite and narrow pigmented distal sclerite (Fig. 2C); fore wing vein $c u-a$ distinctly proximal to $R s \& M$ (Fig. 11A).

Enicospilus merdarius (Gravenhorst, 1829)

- Fore wing lacking central sclerite and with very faint distal sclerite (Fig. 2D); fore wing vein $\mathrm{cu}-\mathrm{a}$ opposite vein $R s \& M$ (Fig. 11B).

Enicospilus repentinus (Holmgren, 1860)

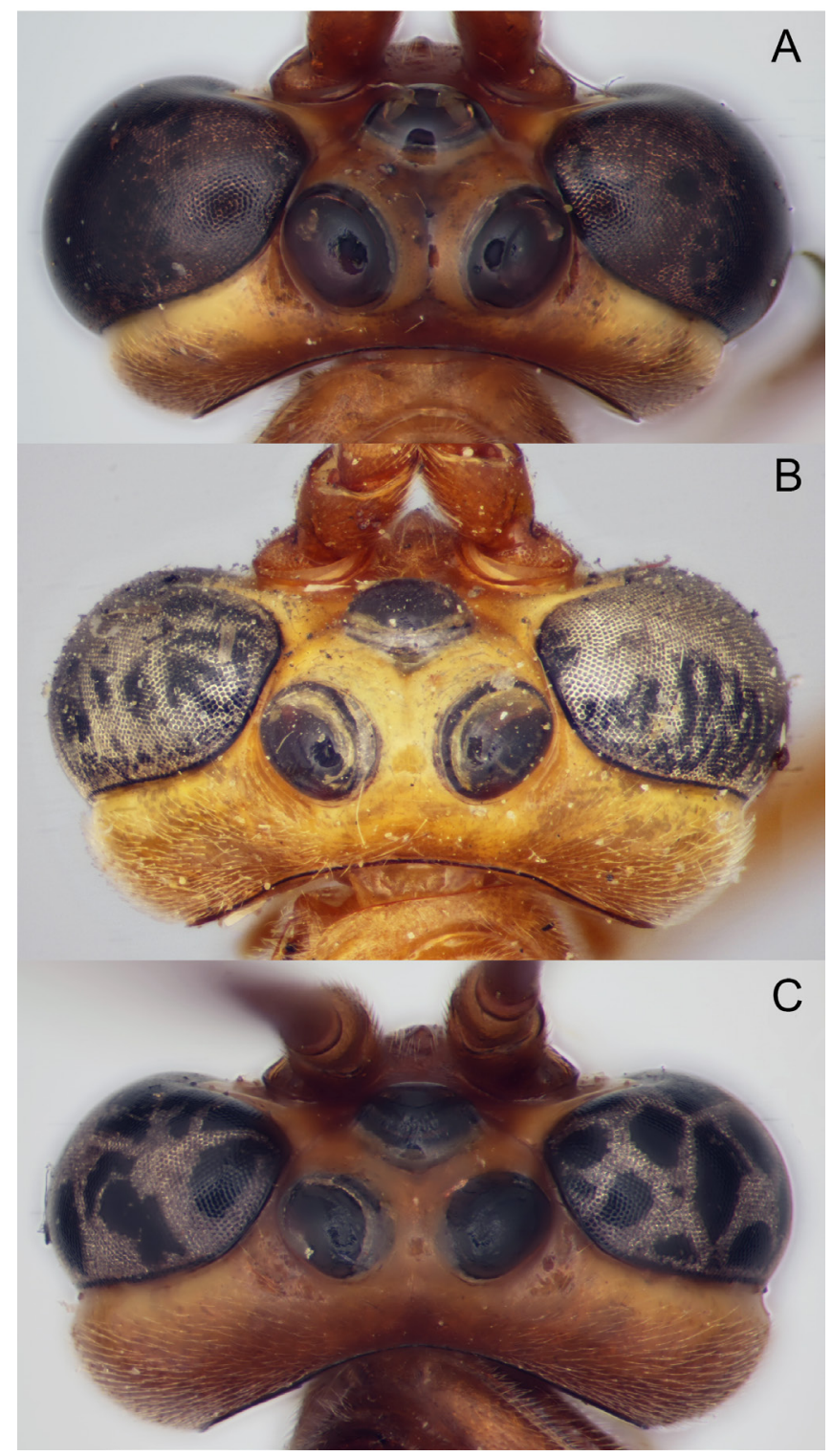

Fig. 4. Head, dorsal view. A. Enicospilus cerebrator Aubert, 1966. B. E. adustus (Haller, 1885). C. E. myricae sp. nov. 
Enicospilus adustus (Haller, 1885) stat. rev.

Figs 4B, 5B, 6B, 7A, 8A, 9A, 15A, 17, 18A

Ophion adustus Haller, 1885: 200.

Enicospilus merdarius - auctt., misidentification (e.g., Gauld \& Mitchell 1981; Horstmann 1997).

\section{Status and taxonomy}

As explained above, unfortunately the species generally known as Enicospilus merdarius (citations can be traced through Yu et al. 2012, including the inevitable gross misidentifications) is not conspecific with the lectotype, as designated by Fitton (1984). The next available name and, surprisingly, the only name currently placed in synonymy with E. merdarius, is Ophion adustus Haller, 1885 (Horstmann 1997). Unfortunately, the application of E. adustus is not straightforward either; there is no published type depository for Ophion adustus and it appears that nobody has ever referred to a type, if any existed, since Haller (1885) described the species. Haller's description is sufficient to identify his species as either $E$. cerebrator or E. merdarius in the sense of almost all subsequent authors (Haller describes the metasoma as being dark ventrally from the third tergite, which is a frequent discolouration in ophionines). Given that E. merdarius in the traditional sense is a widespread species in Europe we aim to preserve some nomenclatural stability by designating a neotype for Enicospilus adustus. Haller's types (he mentions two specimens) cannot be found (Horstmann 1997; H. Baur, A. Müller pers. comm., regarding Swiss collections) and are presumed lost or destroyed. We here designate a neotype, collected in Switzerland, as was Haller's specimen, and which is equivalent to the segregate after E. cerebrator and E. myricae sp. nov. have been separated. Neotype female: Switzerland, "dübdf" [Dübendorf], "E. merdarius", "Ophion adustus Haller, 1885 neotype $q$ des. G. Broad 2013" (ETHZ). The fore wing sclerites and a dorsal view of the mesosoma are illustrated in Fig. 17. Across Europe, E. merdarius in the old sense is a variable taxon, which prompted Aubert (1966) to separate off E. cerebrator. What remains under the name $E$. adustus may still comprise more than one species, lacking the distinctive features of other species; however, British specimens are rather uniform and very similar to the neotype.

This is a fairly widespread but apparently uncommon species, reared from Noctuidae that feed on low vegetation. We have seen only one reared specimen, from an uncertain host.

\section{Material}

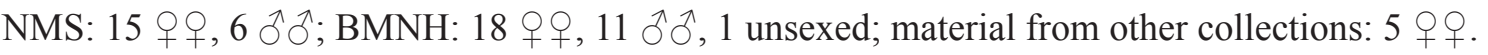

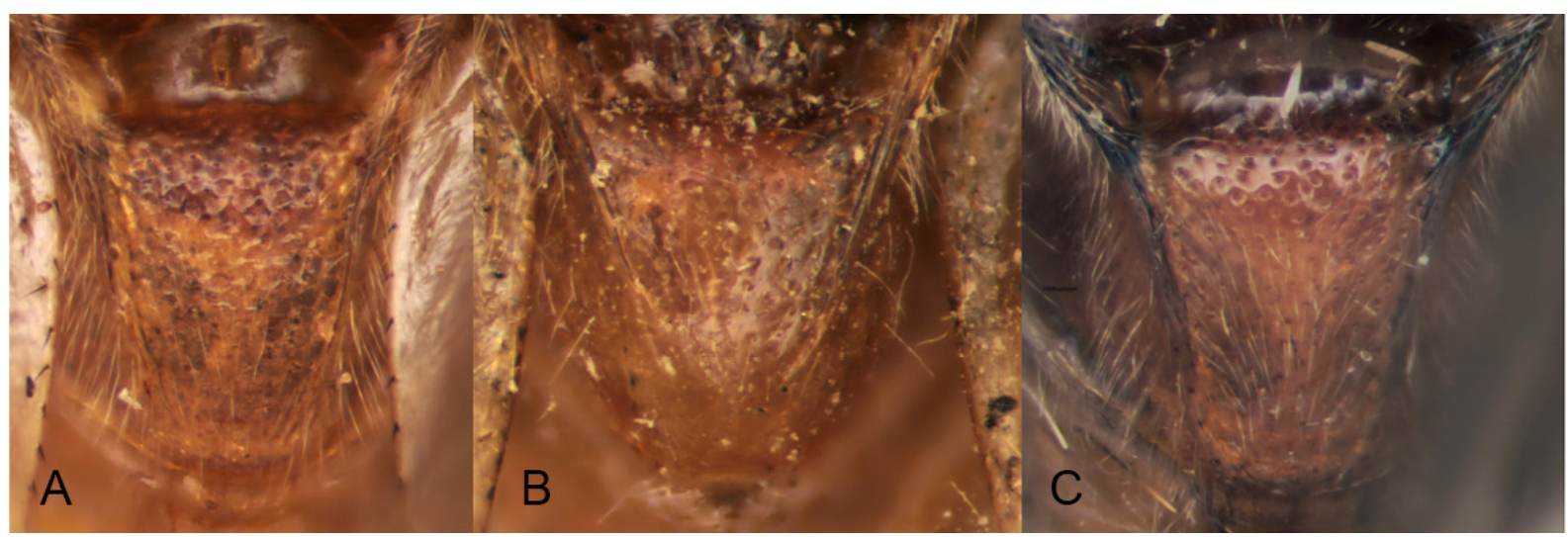

Fig. 5. Scutellum. A. Enicospilus cerebrator Aubert, 1966. B. E. adustus (Haller, 1885). C. E. myricae sp. nov. 


\section{Distribution (Fig. 18A)}

England: VCs 4, 15, 16, 17, 22, 24, 25, 26, 28, 29, 57; Scotland: VCs 75, 85, 86, 94, 96, 99, 110; Ireland: H16; Channel Islands: Jersey.

Additional material in NMS: Bulgaria: Aksakovo, Silistra region, Varna region; France: Côte-d'Or, Dordogne, Lot-et-Garonne; Hungary: Bugac; Italy: South Tyrol.

Flight time (non-reared material)

July-September, with one outlying November date, but $90 \%$ of specimens are concentrated in JulyAugust.

\section{Host}

The only host record is of one specimen labelled as having been reared (M.R. Britton) from either Blepharita adusta (Esper) or Lacanobia oleracea (Linnaeus) (both Noctuidae) (NMS).

Despite the coincidence of the species name, Haller's specimens were not reared but were caught in the daytime, basking on vegetation (Haller 1885). There are no obvious habitat preferences discernible from the collection data.

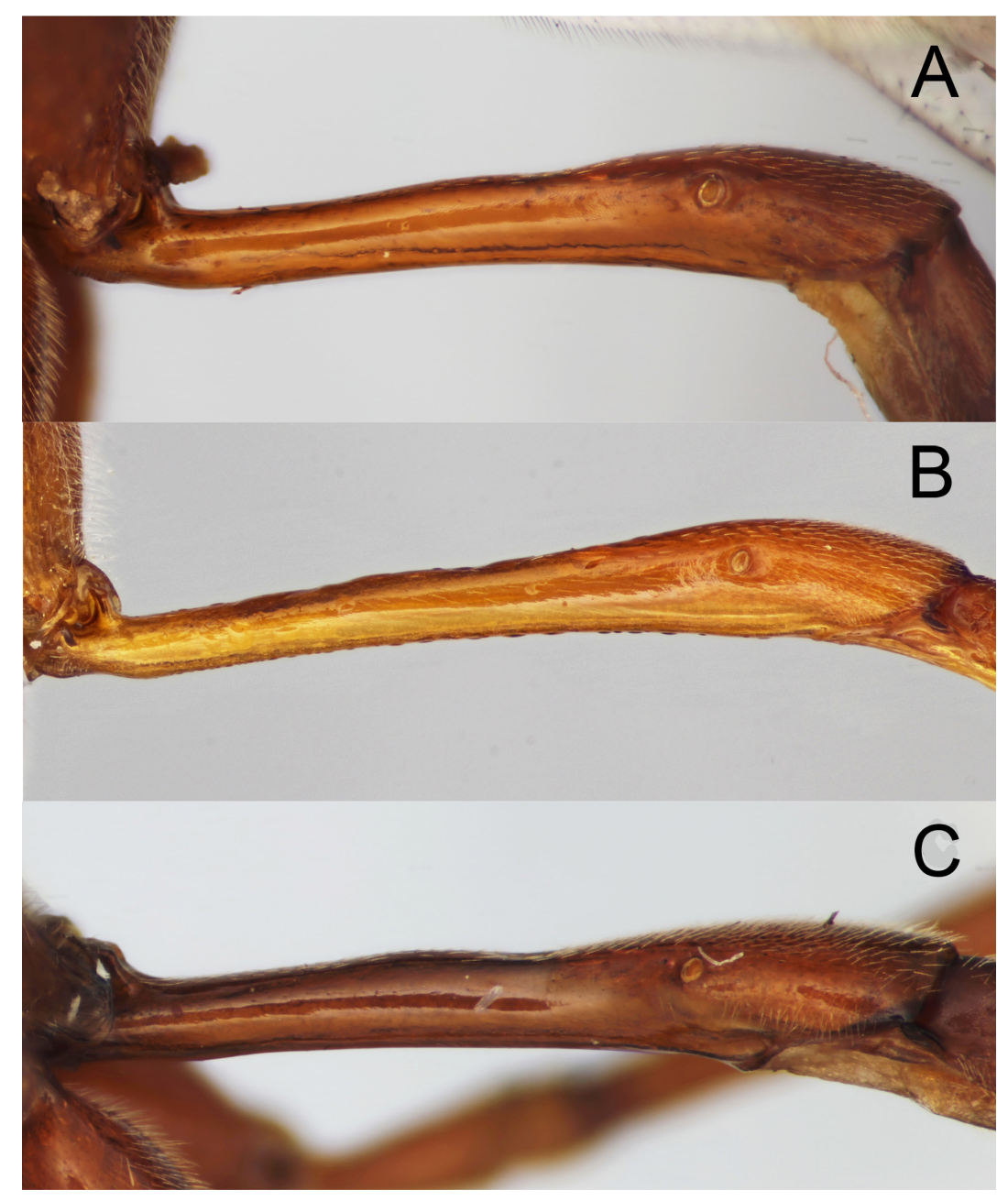

Fig. 6. First metasomal segment (anterior to left). A. Enicospilus cerebrator Aubert, 1966. B. E. adustus (Haller, 1885). C. E. myricae sp. nov.. 


\section{Remarks}

Identification is relatively straightforward but not all material of "E. merdarius" from light traps was retained until it was realised that E. cerebrator had been overlooked in Britain. Enicospilus adustus is a large, testaceous species, lacking dark markings except, sometimes, for discolouration of the metasomal sternites and laterotergites. Morphologically it is very similar to E. combustus and E. ramidulus, which each have distinctive colour characters. The long antennae (58-69 flagellar segments in British specimens, usually in the range of 60-65, modal value 63; 62 flagellar segments in the neotype) with elongate preapical flagellar segments serve to distinguish $E$. adustus from E. cerebrator, together with the form of the scutellum and the slightly wider temples. Enicospilus myricae sp. nov. differs in several respects (see notes under that species) and the antenna is intermediate in length between E. adustus and E. cerebrator. Some European specimens of $E$. adustus are noticeably larger, with a more pronounced posterior ridge to the scutellum and there may be additional undescribed species in this complex. In both E. adustus and E. cerebrator the anterior transverse carina of the propodeum varies from complete to largely absent.

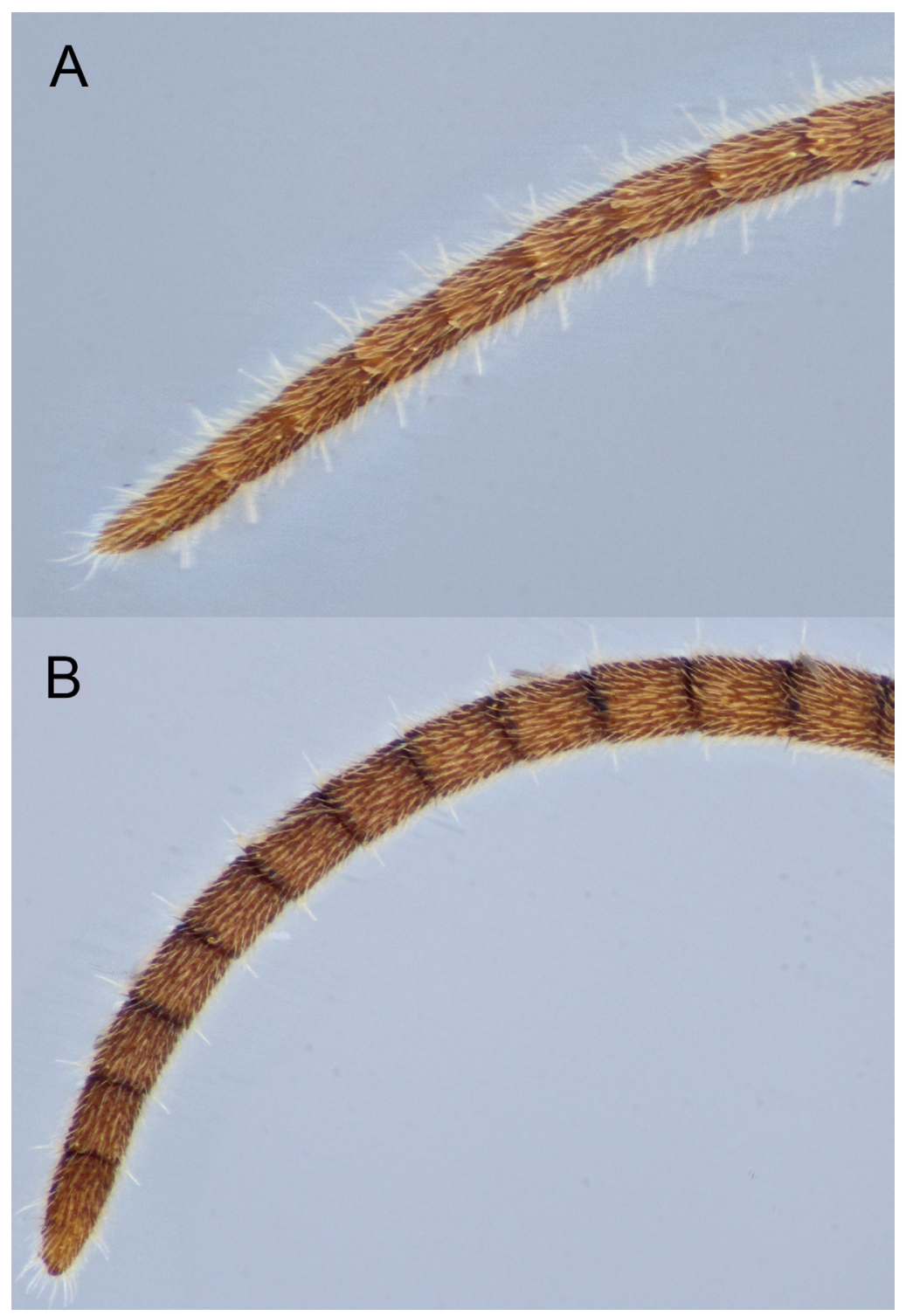

Fig. 7. Distal flagellar segments. A. Enicospilus adustus (Haller, 1885). B. E. cerebrator Aubert, 1966. 
Enicospilus cerebrator Aubert, 1966

Figs 4A, 5A, 6A, 7B, 8B, 15B, 18B

Enicospilus cerebrator Aubert, 1966: 42; holotype § examined (MZLS).

\section{Status}

New to Britain. Although widely recorded across the Western Palaearctic (e.g. Aubert 1966; Izquierdo 1984), British authors have overlooked E. cerebrator; however, this species turns out to be rather widespread in south-east England (one more northerly record, from Yorkshire) where it has been reared from several species of Hadena Schrank, 1802 and Hecatera Guenée, 1852 (Notuidae: Hadeninae)

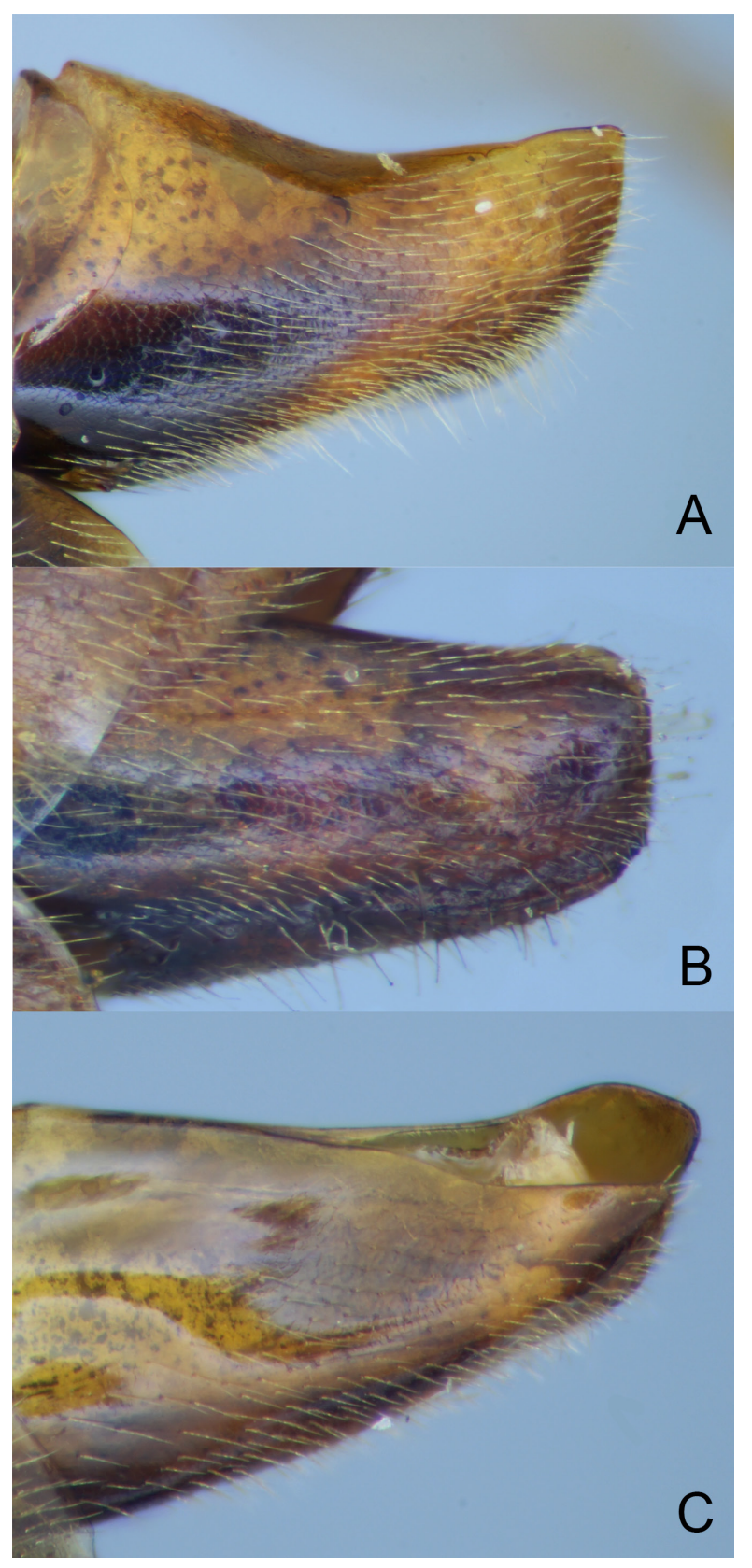

Fig. 8. Male parameres (claspers). A. Enicospilus adustus (Haller, 1885). B. E. cerebrator Aubert, 1966. C. E. myricae sp. nov. 
whose larvae feed in seedheads or on flowers. There are three specimens reared from Hecatera dysodea (Denis \& Schiffermüller, 1775), which has a restricted range in England and south Wales (Hill et al. 2010) and was extinct in Britain for many years; it is fairly frequently the case that there are good numbers of parasitoid rearings from rare hosts (e.g. Enicospilus merdarius), which are targeted by entomologists in preference to the more widespread host species (note the paucity of host records for $E$. adustus and E. combustus).

\section{Material}

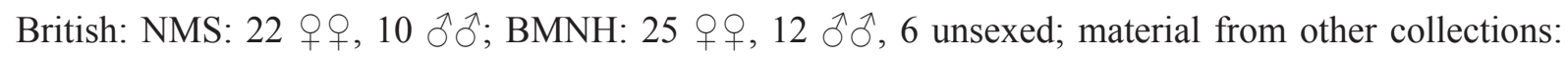
11 웅, 5 ふึે, 1 unsexed.

\section{Distribution (Fig. 18B)}

England: VCs 1, 11, 15, 16, 17, 19, 20, 22, 24, 25, 26, 28, 30, 32, 62.

Additional material in NMS: Bulgaria: Aksakovo; France: Hérault, Lot-et-Garonne, Vaucluse; Hungary: Bugac; Italy: South Tyrol.

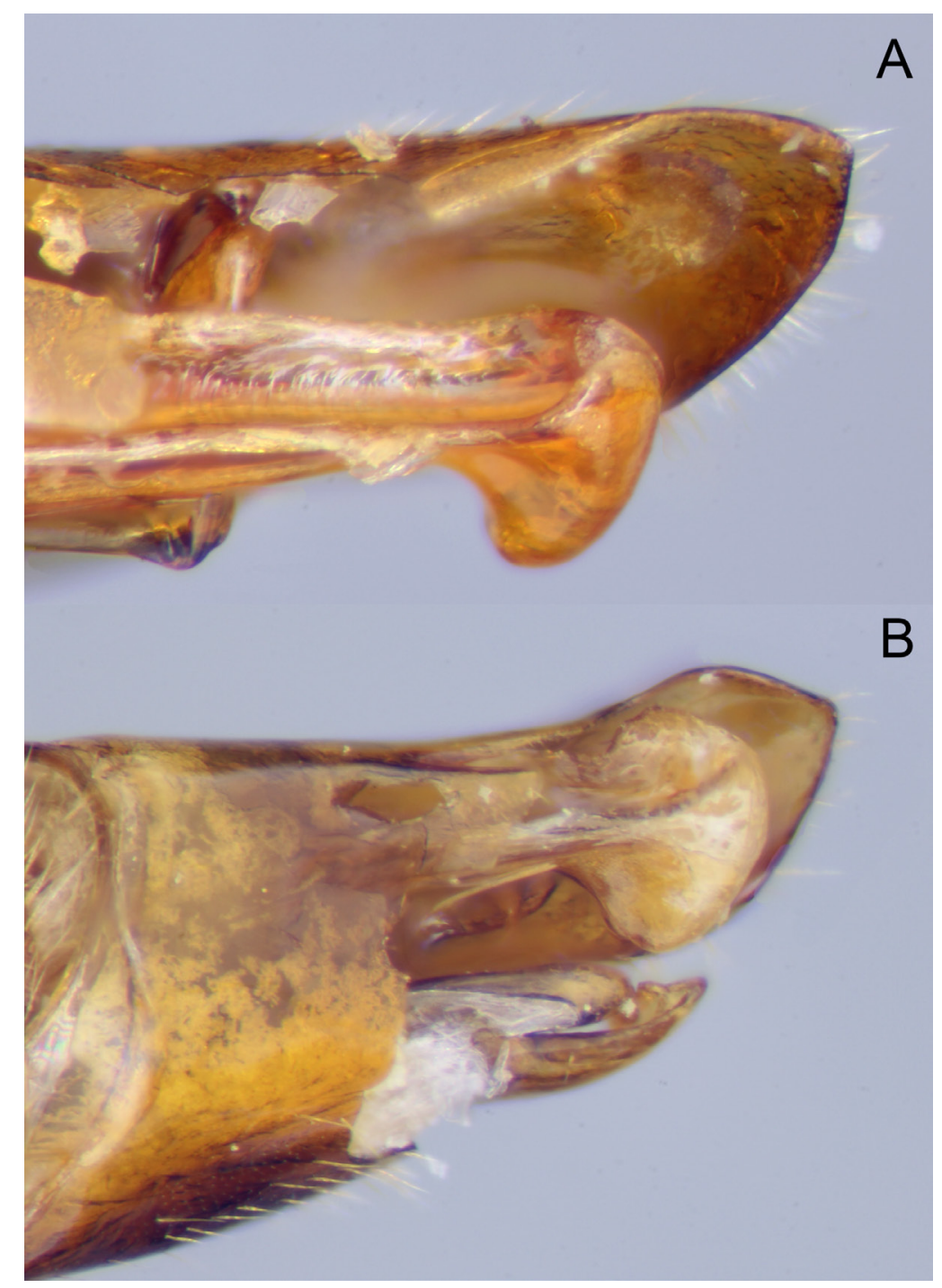

Fig. 9. Male aedeagus. A. Enicospilus adustus (Haller, 1885). B. E. myricae sp. nov. 
Flight time (non-reared material)

May-August, with 51\% having been collected in July; one specimen is labelled as "xi". From a series in NMS collected at Dungeness (coll. C.W. Plant) from mid-May to late July, it seems that E. cerebrator is plurivoltine (at least bivoltine), in contrast to other British Enicospilus, although May specimens have not been seen from any other locality.

\section{Hosts}

Hadena albimacula (Borkhausen, 1792) (3) (G.T. Lyle, A. Wander; BMNH); Hadena irregularis (Hufnagel, 1766) (13, from one site and collector, C. Morley; BMNH); Hecatera dysodea (3) (R. Hayward, J. Platts, I. Sims; NMS); Hecatera bicolorata (Hufnagel, 1766) (4) (Harwood, C.G. Nurse; BMNH, WML) (all Noctuidae). Two specimens, seemingly from one collecting event, are labelled as having been reared from "Anticlea sinuata" (= Catarhoe cuculata (Hufnagel, 1767)) (Geometridae), which can be ruled out on size alone.

\section{Remarks}

Enicospilus cerebrator is a smaller species than E. adustus, with more strongly narrowed temples and a rather distinctive scutellum. The antennal flagellum is shorter than in E. adustus or E. myricae sp. nov. (51-56 flagellar segments, modal value 53), with stouter preapical flagellar segments than in E. adustus; the scutellum appears more parallel-sided, broader posteriorly, bordered posteriorly by a slightly raised ridge and with the sides more abruptly curved posteriorly than in similar species; the surface of the scutellum is more matt than in similar species; the male parameres are square-ended (Fig. 8B) compared to the more tapering parameres of E. adustus and E. myricae sp. nov.

Enicospilus combustus (Gravenhorst, 1829)

Figs 14A, 18C

Ophion combustus Gravenhorst, 1829: 701.

\section{Status}

A distinctive species of mainly southern distribution. It has not been found in Scotland. Reared from Melanchra persicariae (Linnaeus, 1761) (Noctuidae).

\section{Material}

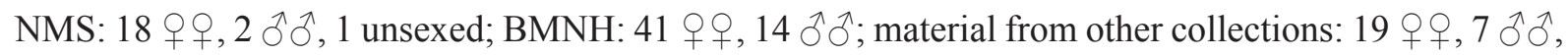
3 unsexed.

\section{Distribution (Fig. 18C)}

England: VCs 1, 2, 3, 7, 11, 13, 15, 17, 20, 21, 22, 23, 24, 25, 26, 28, 29, 36, 58, 62, 64, 65; Wales: VC 41, 52; Channel Islands: Sark.

Flight time (non-reared material)

July-October, with the majority in August-September; is on the wing later in the year than E. adustus, E. cerebrator and E. ramidulus.

\section{Hosts}

Melanchra persicariae (1) (Noctuidae), reported via iSpot (www.ispot.org.uk), reared in Norfolk, released but identified from a photo. Additionally, there are two females in H. Schnee's personal collection also reared, in Germany, from M. persicariae (Dübener, coll. ix.1985, em. v/vi.1986). 


\section{Remarks}

Although very similar in general morphology to E. adustus and E. ramidulus, the colour pattern of $E$. combustus is distinctive, with the mesosoma extensively black, and the antennae have more flagellar segments (62-70 flagellar segments, modal number 65), especially compared to E. ramidulus, which shares a black-tipped metasoma. Other than colour pattern, though, there seem to be no reliable morphological distinctions from E. adustus, apart from a greater number of antennal segments (but with an overlapping range).

Enicospilus cruciator Viktorov, 1957

Enicospilus cruciator Viktorov, 1957: 205.

\section{Material}

Not British. NMS: FRANCE: 1,+ 2 $\widehat{\jmath}$, Aude, 26-31 May 2012 (M.R. Shaw).

\section{Remarks}

This species is very similar to E. merdarius (see notes under E. merdarius) and it is possible that some other continental specimens identified as E. merdarius (or E. tournieri) in BMNH and NMS in fact belong to this species.

\section{Enicospilus inflexus (Ratzeburg, 1844)}

Figs $3 \mathrm{~A}, 12,20 \mathrm{~A}$

Ophion inflexus Ratzeburg, 1844: 102.

\section{Status}

A relatively widespread parasitoid of Lasiocampa, and possibly other Lasiocampidae, particularly on heaths and moorland.

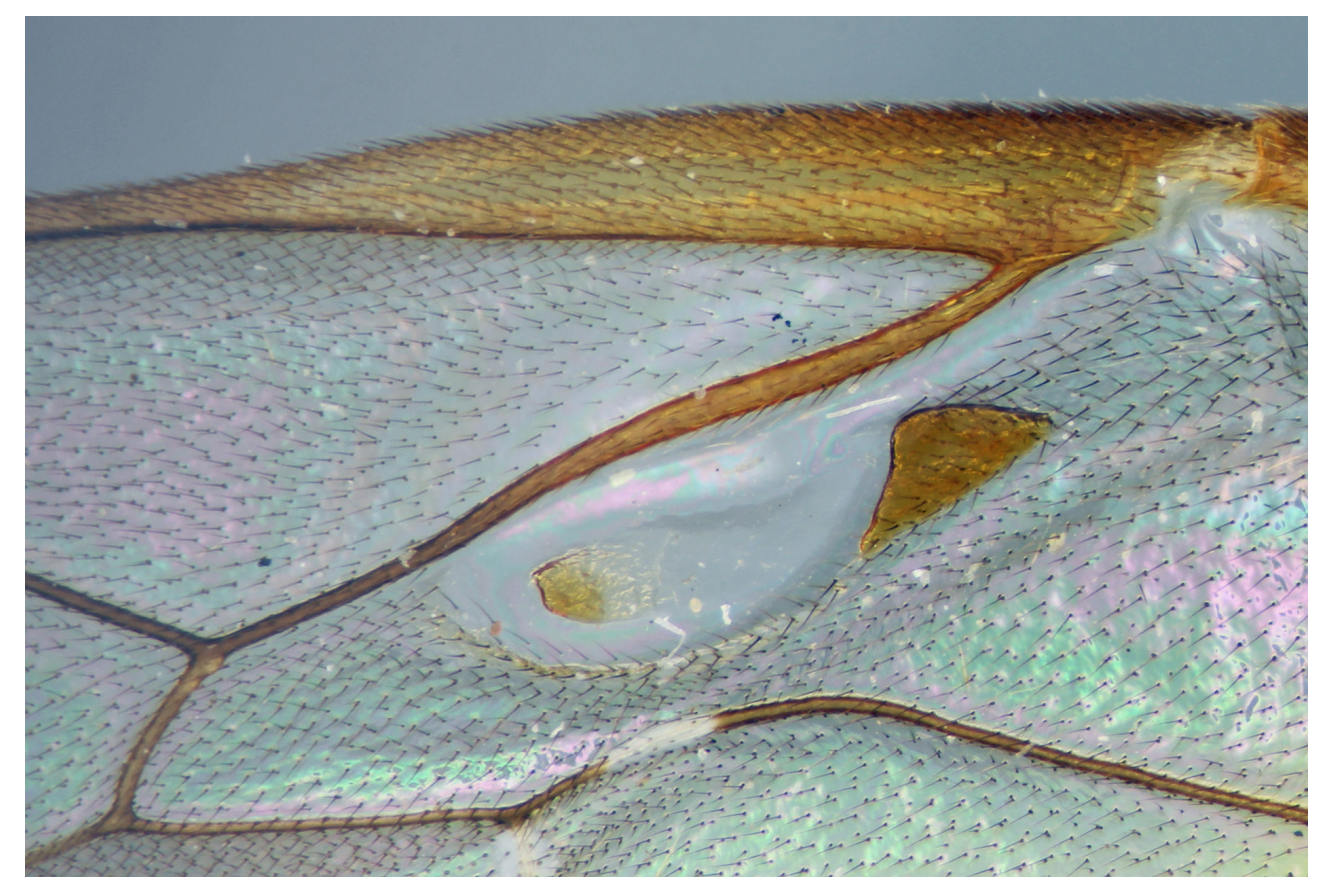

Fig. 10. Fore wing sclerites of Enicospilus myricae sp. nov. 


\section{Material}

NMS: 16 우, $7 \hat{\jmath} \hat{\jmath}, 1$ unsexed; BMNH: 12 qㅇ, $8 \hat{\partial} \hat{\partial}, 1$ unsexed; material from other collections: 17 우, 3 के $\hat{0}, 1$ unsexed.

\section{Distribution (Fig. 20A)}

England: VCs 1, 2, 3, 5, 9, 10, 11, 13, 15, 17, 28, 31, 39, 50, 57, 64, 67, 69; Scotland: VCs 72, 87, 89, 95, 97, 98, 99, 102, 104, 105, 110; Wales: VC 49.

Flight time (non-reared material)

June-September, with the majority in August.

\section{Hosts}

Lasiocampa quercus (Linnaeus, 1758) (including f. callunae Palmer, 1847) (10) (Lasiocampidae) (T.H. Ford, J.L. Gregory, Harwood, A. Kennedy, D.K. Kevan, M. R. Shaw, C.H.S. Vimter, L.Wakely, P. Yarlett) (BMNH, NMS); one specimen in BMNH labelled as reared from Euthrix potatoria (Linnaeus, 1758) (Lasiocampidae) (R. South), and another labelled as ex Cerura vinula (Linnaeus, 1758) (Notodontidae) (A.H. Sperring), which seems very improbable.

\section{Remarks}

Along with E. undulatus, with which it has frequently been confused, E. inflexus belongs to a distinctive group of species (in older literature sometimes referred to as the genus Allocamptus) that lack fore wing sclerites, are very large and have a strongly sinuous fore wing vein $R s+2 r$. Compared to E. undulatus, E. inflexus has more narrowed temples, giving it a less buccate head, but it is otherwise very similar.

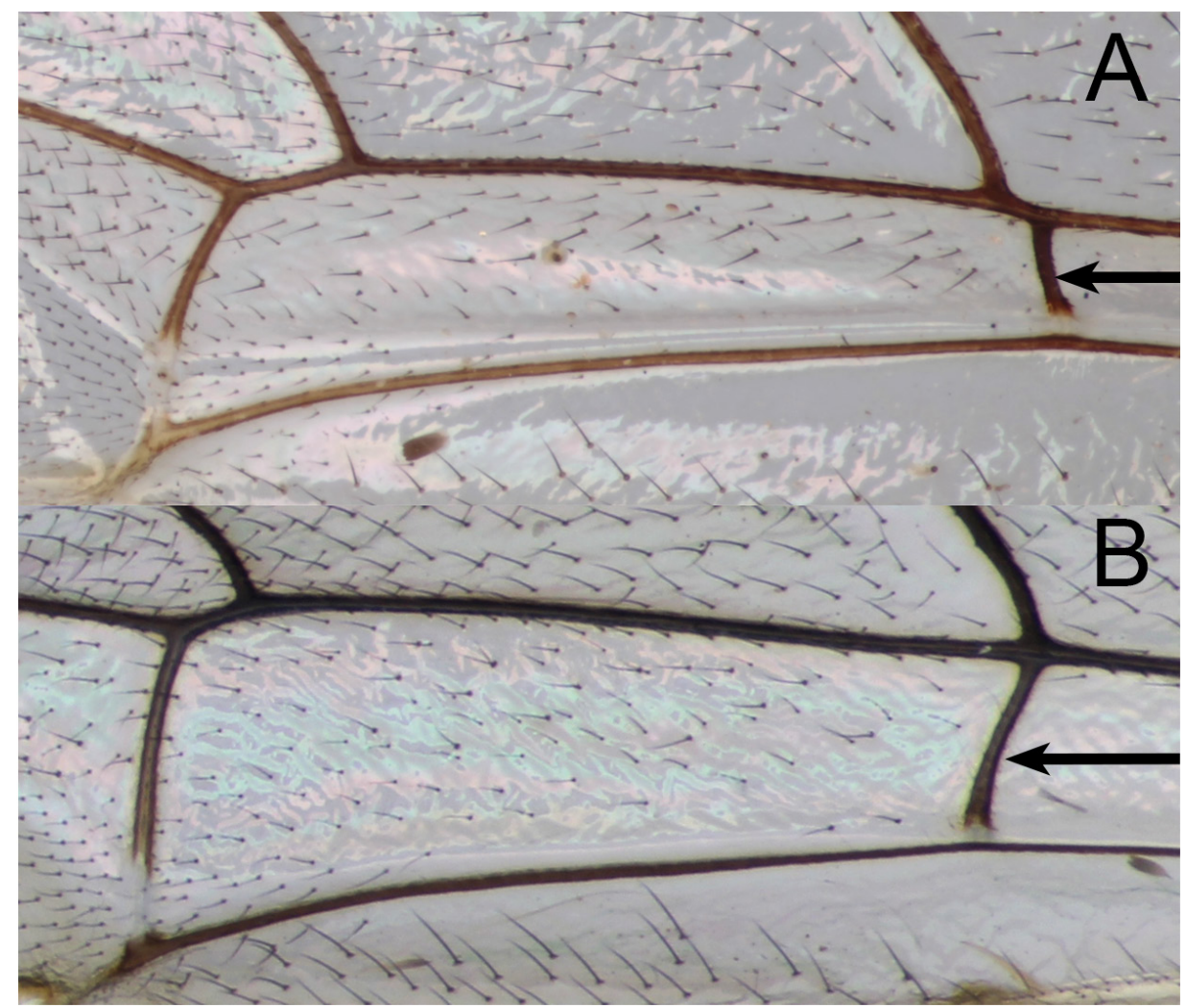

Fig. 11. Fore wing (distal to left), vein $\mathrm{cu}-a$ arrowed. A. Enicospilus merdarius (Gravenhorst, 1829). B. E. repentinus (Holmgren, 1860). 
Enicospilus merdarius (Gravenhorst, 1829)

Figs 1, 2C, 11A, 13A, 19A

Ophion merdarius Gravenhorst, 1829: 698; lectotype $\curvearrowright$, OUMNH, examined.

Ophion tournieri Vollenhoven, 1879: 61, pl. 39; syn. nov.

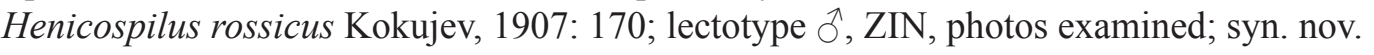

Enicospilus contributus Shestakov, 1926: 256; syn. nov.

Enicospilus repentinus - misidentification (Gauld 1973).

\section{Status}

As described in the "Taxonomy of British Enicospilus" section above, the lectotype male of Ophion merdarius is a specimen of the species usually called E. tournieri. The (probably non-British) female paralectotype is a specimen of Enicospilus adustus (i.e., the usual interpretation of the name), so the choice of lectotype was unfortunate. We have not examined type material of Ophion tournieri or Enicospilus contributus as these types cannot be located; instead we have followed the synonymies (under tournieri) of Aubert $(1962,1964)$ and Viktorov (1957). The type of E. contributus should be in ZIN but could not be located (A. Khalaim, pers. comm.). The whereabouts of the type male of $O$. tournieri is a mystery; Townes et al. (1965) report the type depository as the Muséum national d'Histoire naturelle, Paris, but it cannot be found there (A. Touret-Alby, pers. comm.) and it seems unlikely when most of the Vollenhoven's types were deposited in Dutch collections. There is also no trace of a type in Naturalis, Leiden (F. Bakker, pers. comm.), which includes the former Amsterdam collections. The type locality of Switzerland makes it likely that $O$. tournieri is a synonym of $E$. merdarius rather than $E$. cruciator, described from Turkmenistan and apparently more of a species of hot, dry climates (judging by published records and the collections of $\mathrm{BMNH}$ ).

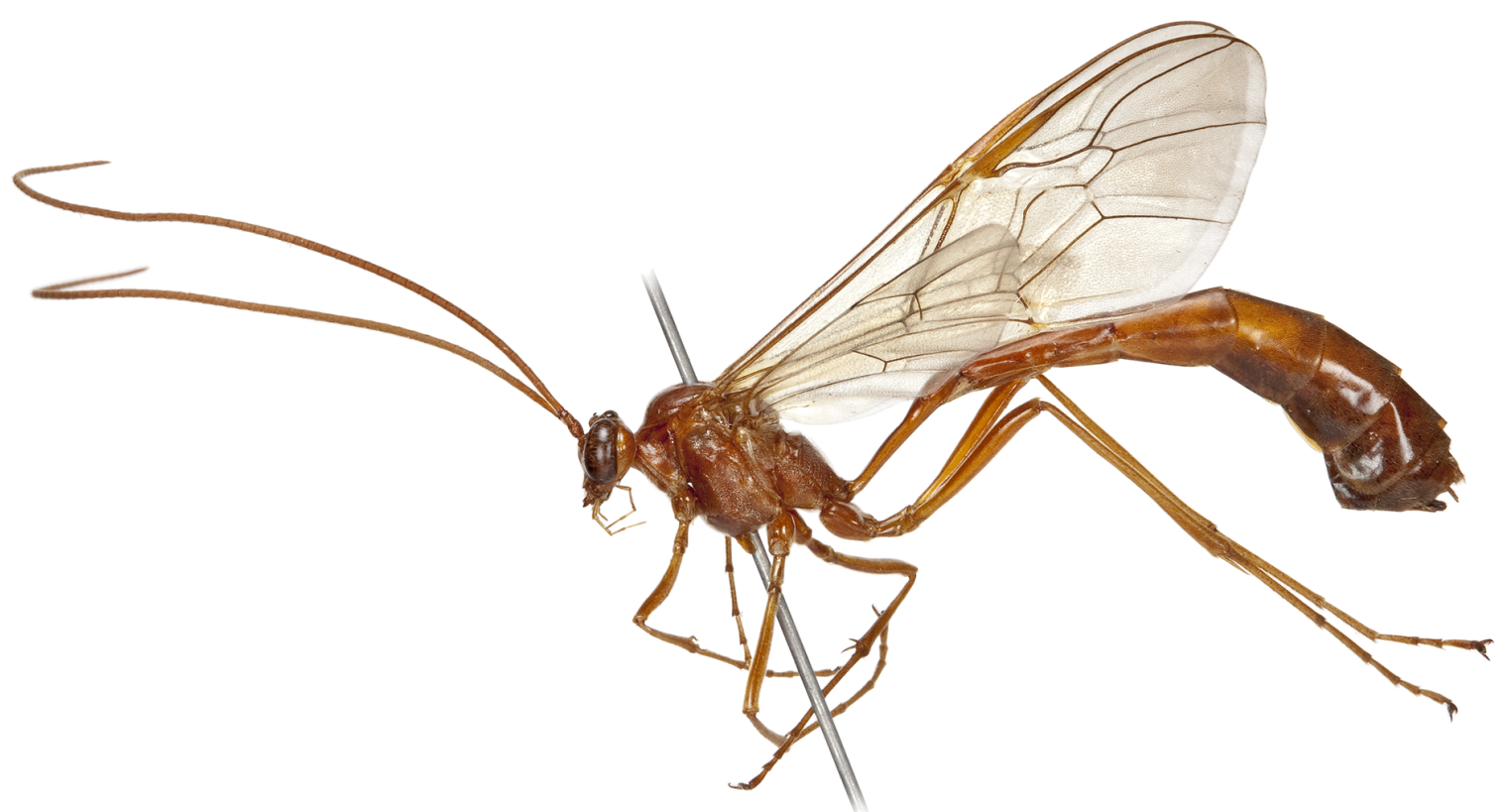

11111111111

Fig. 12. Enicospilus inflexus (Ratzeburg, 1844),, , Tredinnick Stack, England, BMNH(E) 962205, habitus. Scale bar $=10 \mathrm{~mm}$. 
Restricted to a few coastal sites in England and Scotland. Only reared from Agrotis ripae (Hübner, 1823) (Noctuidae) (7 rearings), which inhabits the strandlines of sandy beaches and is very localised. The apparent host specificity of $E$. merdarius may be a result of the restricted noctuid fauna in its habitat. Gauld (1973) recorded E. repentinus as a British species but, based on his description of the species as being coastal, and the lack of true E. repentinus in the BMNH collections until recently, it seems he was describing E. merdarius; in fact, Sperring (1952) had already published on E. tournieri as a British species, with a host record (specimens in BMNH and BENHS).

A

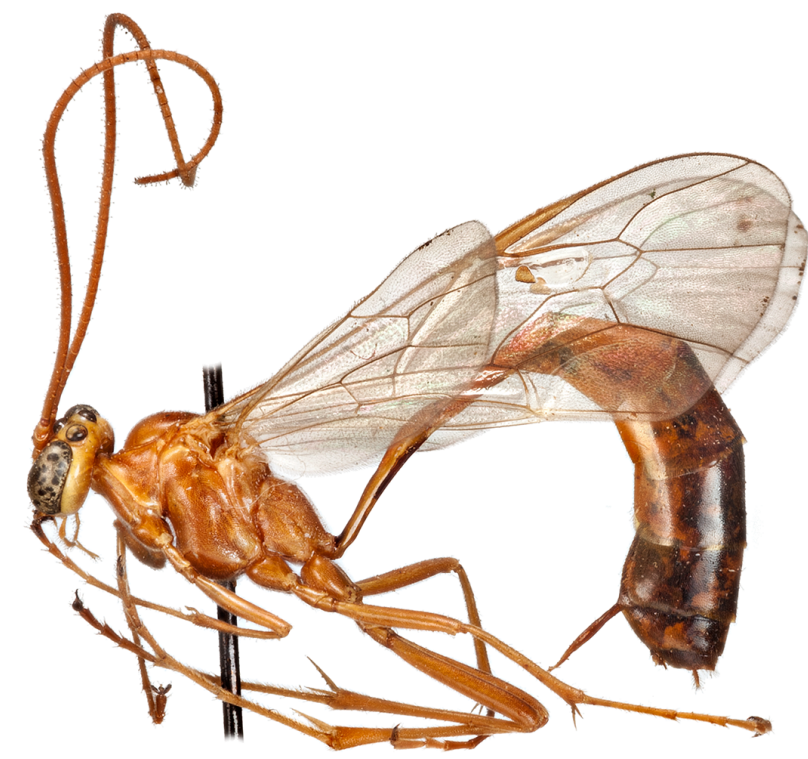

| 1111111111

B

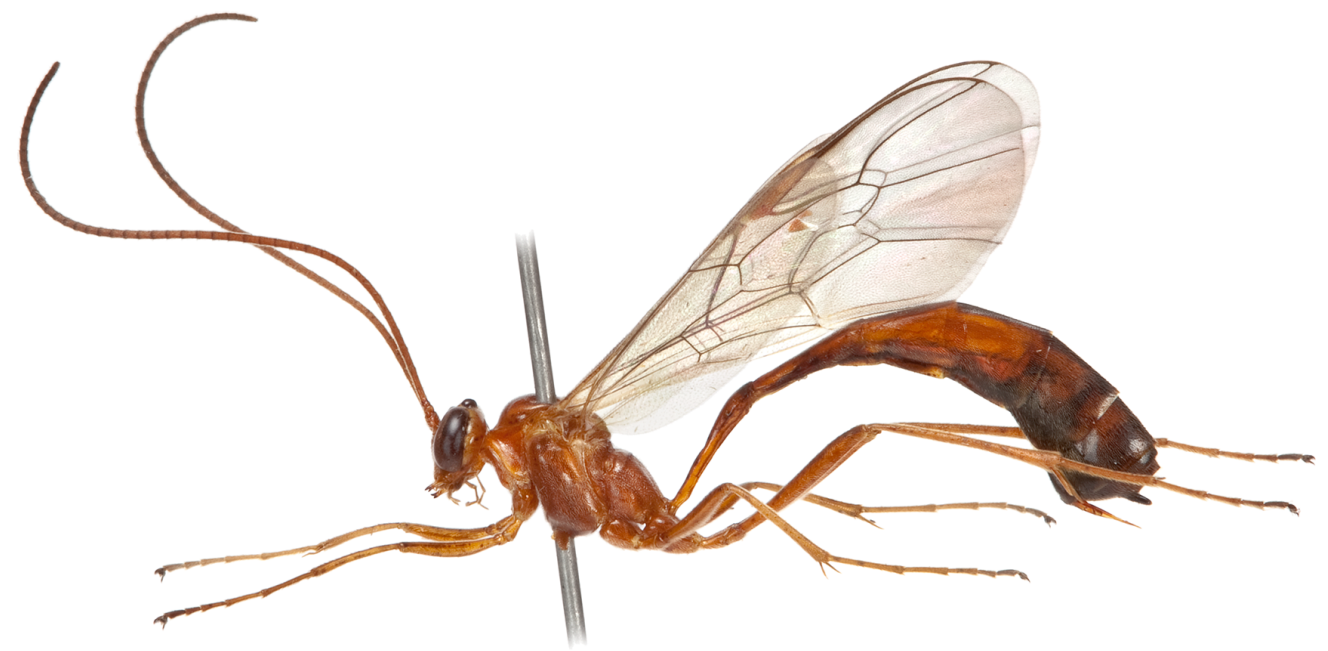

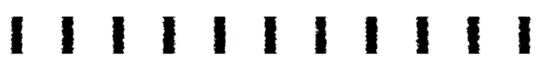

Fig. 13. Habitus. A. Enicospilus merdarius (Gravenhorst, 1829), ㅇ, Eastbourne, England, BMNH(E) 1022376. B. E. repentinus (Holmgren, 1860), , , Aldbury, England, BMNH(E) 962208. Scale bars $=10 \mathrm{~mm}$. 


\section{Material examined}

ENGLAND: 1 \&, Dawlish Warren (VC 3), 14 Aug. 1977 (A.A. Allen) (NMS); 1 ठ, Winterton (VC 27), ex Agrotis ripae coll. as larva 7 Sep. 1988, em. spring 1989 (J.M. Chalmers-Hunt) (NMS); 1 , $1 \mathrm{O}$, Hayling Island (VC 11), ex A. ripae coll. as larvae, em. [dates presumed to be emergence dates] 28 Jul., 17 Aug. 1951 (A.H. Sperring); 1 unsexed (VC 11), ex A. ripae coll. as larva, Aug. 1931 (A.H. Sperring); 1 Oे, East/West Wittering (VC 13), ex A. ripae coll. as larva 4 Aug. 1932 (A.J. Wightman); 1 q, Eastbourne (VC 14), Aug. 1900 (C.G. Nurse); 1 \&, Clacton (VC 19), Aug. 1926 (Harwood); 1 ô,

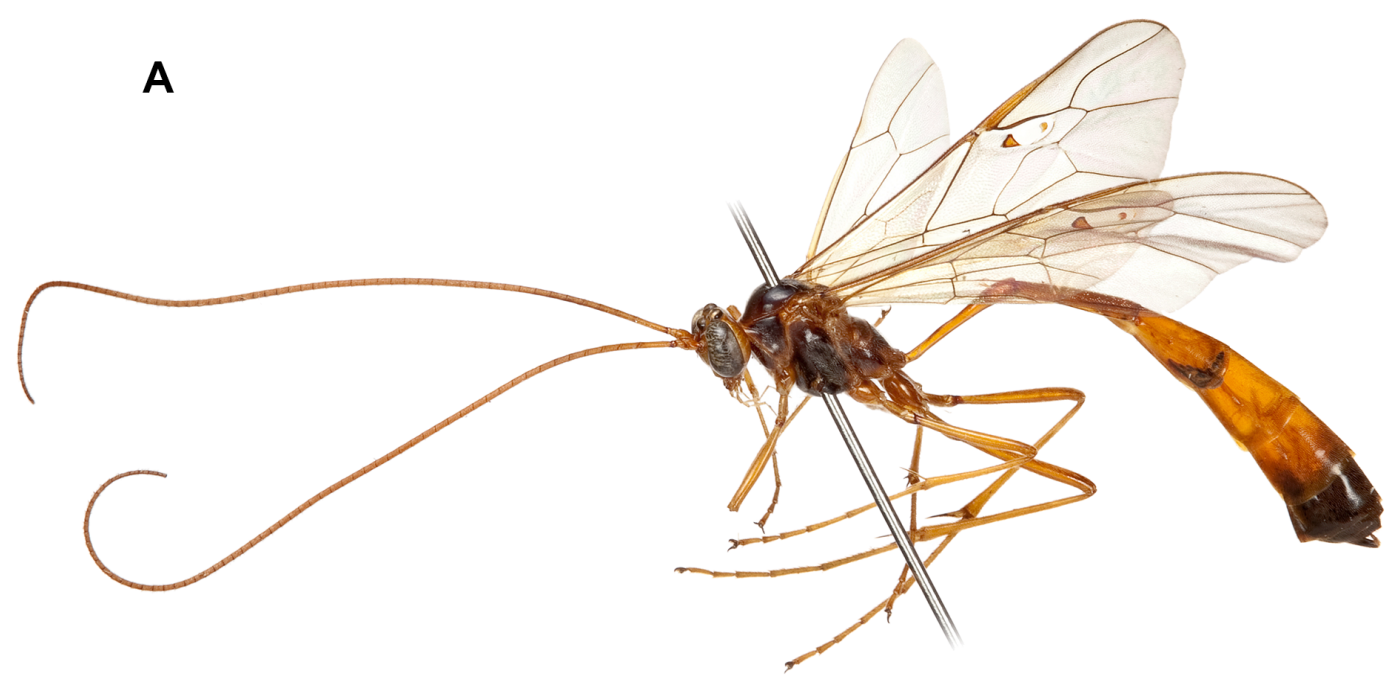

1||||||||||

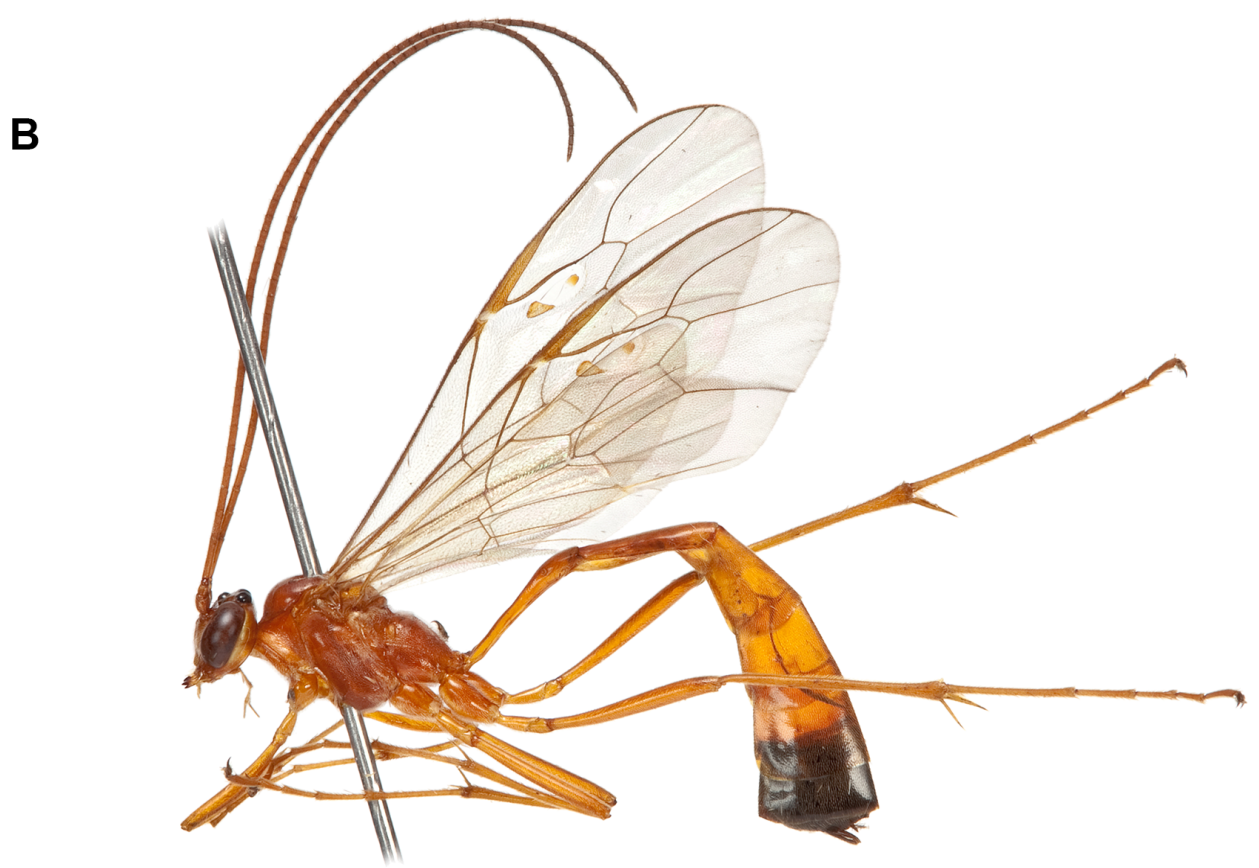

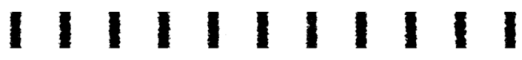

Fig. 14. Habitus. A. Enicospilus combustus (Gravenhorst, 1829), 9 , Bath, England, BMNH(E) 962204. B. E. ramidulus (Linnaeus, 1758), $q$, Cornwall, England, BMNH(E) 962207. Scale bars $=10 \mathrm{~mm}$. 


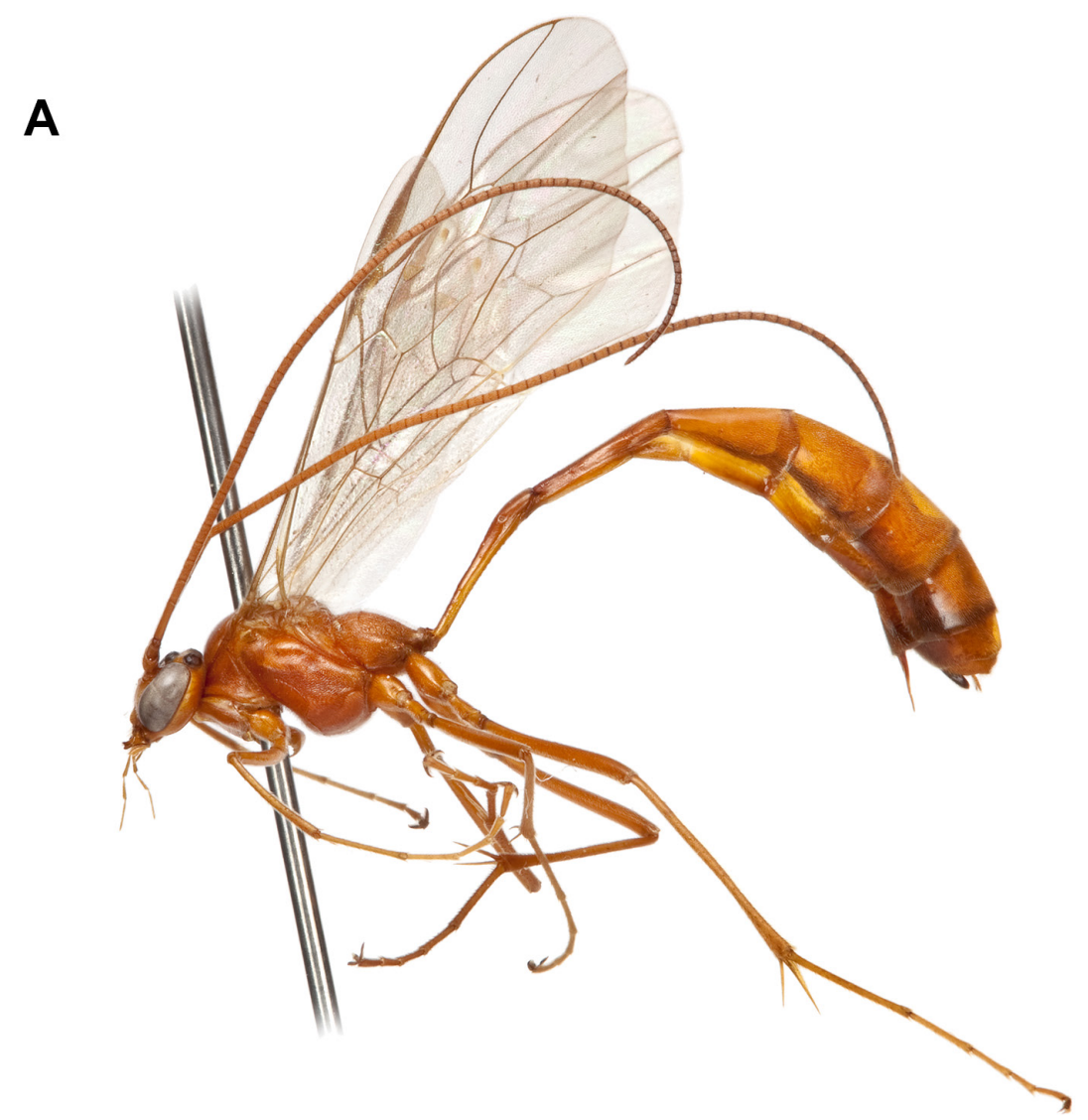

| | | | | | | | | | | |

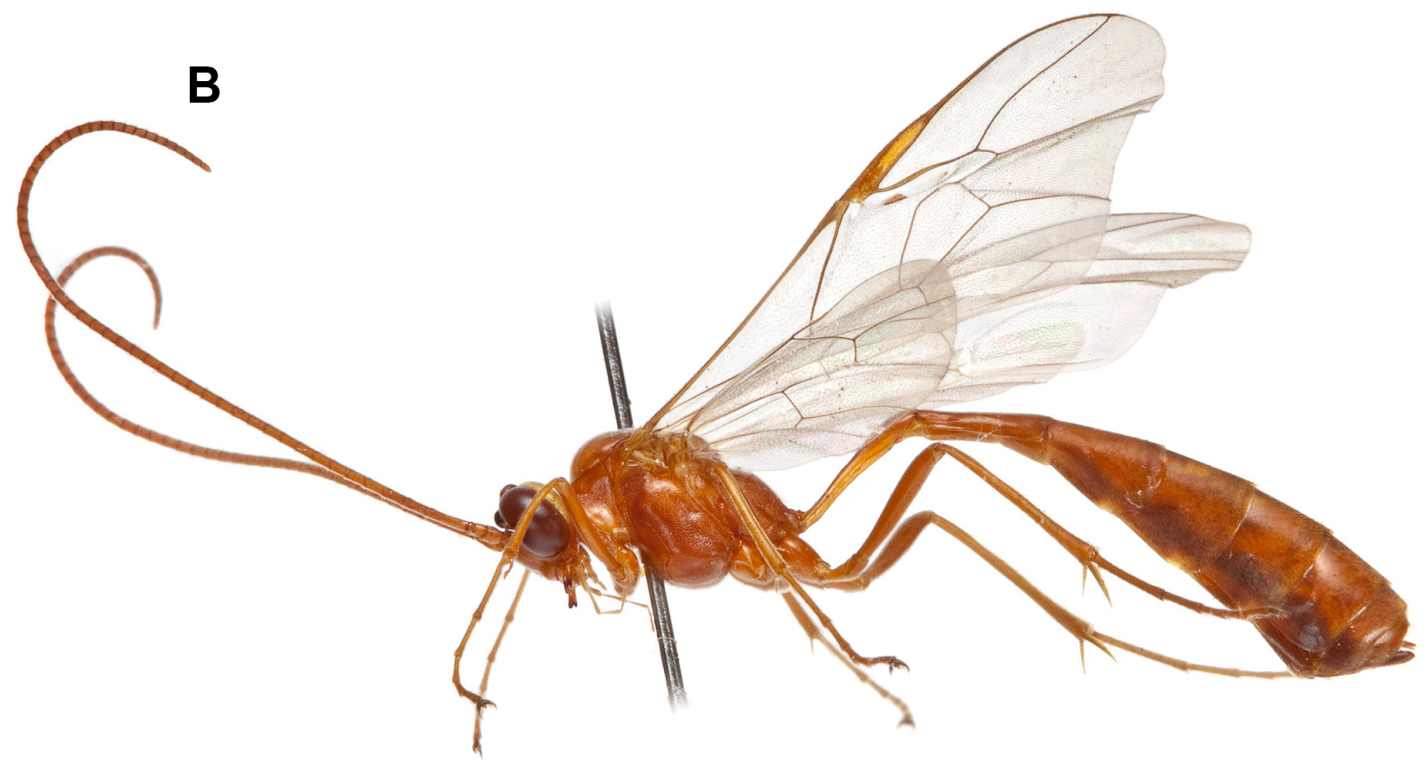

\section{| | | | | | | | | | | |}

Fig. 15. Habitus. A. Enicospilus adustus (Haller, 1885), o, Tentsmuir, Scotland, BMNH(E) 962202. B. E. cerebrator Aubert, 1966, $q$, Calshot, England, BMNH(E) 962203. Scale bars $=10 \mathrm{~mm}$. 
Freshwater Bay [there are Freshwater Bays in Dorset and on the Isle of Wight], <1904 (T.E. Marshall) (all BMNH); 1 ô, Hayling Island (VC 11), ex A. ripae coll. as larva, em.[?] 5 Aug. 1951 (A.H. Sperring) (BENHS).

SCOTLAND: 1 ð̊, St Cyrus NNR (VC 91), ex A. ripae em. Jul. 1993 (A.J. Halstead) (NMS).

\section{Additional material in NMS}

BULGARIA: 6 ㅇ, 1 §ै, Aksakovo (C.W. Plant) (NMS).

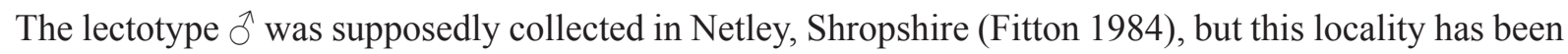
ascribed to most of the British material sent by F.W. Hope to J.L.C. Gravenhorst and seems very unlikely to be the actual collection locality for this sand dune inhabitant: entomologists of that period seemed often to name their home town, presumably to identify specimens as theirs, on what might otherwise be taken as data labels (which were, to say the least, unfashionable at the time).

\section{Remarks}

Most similar in the British fauna to E. repentinus but larger (52-58 flagellar segments, $\mathrm{n}=10$, modal value 52) and with distinct differences in fore wing sclerites and venation; also the propodeum has rather different sculpture, with the rugosity more raised and thus making it less shiny than in E. repentinus. Unlike in E. repentinus, there are some rather vaguely defined pale yellow patches on the mesosoma (Fig. 13A). The non-British Enicospilus cruciator is similar and the two species may well be confused in collections. Judging by Viktorov's (1957) key and photographs of a female and male of the type series, E. cruciator differs from E. merdarius in the longer, less narrowed temples (in dorsal view of the head) and the larger ocellar-ocular gap.

Enicospilus myricae sp. nov. urn:1sid:zoobank.org:act:31771CB3-729B-4157-A201-B6736BBB2800

Figs 4C, 5C, 6C, 8C, 9B, 10, 16, 18D

\section{Diagnosis}

Separated from E. adustus and E. cerebrator by the more rounded temples, wider ocellar-ocular space (especially compared to E. cerebrator), more obvious dorsal "dip" on the first tergite and by the distinctly different aedeagus of the male.

\section{Etymology}

Named after the association with the distinctive habitat of Myrica gale-dominated bog, from which this species was reared.

\section{Material examined}

\section{Holotype}

SCOTLAND: $:$ : "[Scotland] Resipole, Argylls. NM 723645. Orthosia gracilis, Myrica gale coll. 4.7.92, PLE [parasitoid larva erupted] 7.92 em. 7.1993 M.R. Shaw" (NMS).

\section{Paratypes}

SCOTLAND: 2 qq , same data as holotype (NMS); 1 ô, Resipole, Argyllshire, coll. 4 Jul. 1992 (M.R.

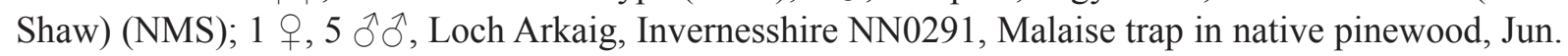
1992 (I. MacGowan) (NMS).

WALES: 1 q, Glamorgan, Kenfig, 30 Jun. 1963 (R.B. Benson) (BMNH). 
ENGLAND: 1 q, Huntingdonshire, Monks Wood NNR, 17-29 Jul. 1978 (M.G. Fitton \& J.S. Noyes) $(\mathrm{BMNH})$.

AUSTRIA: 1 +, Burgenland, Leitha Gebirge, 10-23 Jun. 1956 (E.W. \& I.D. Classey) (BMNH).

\section{Description}

\section{Female}

There is very little variation between specimens; variation is covered in the description. Fore wing length $11-13.5 \mathrm{~mm}$. Antenna with 57-59 flagellar segments $(\mathrm{n}=6)$ (57 in holotype). ${ }^{\text {st }}$ flagellomere about $5 \times$ as long as apically wide, preapical flagellomere $1.5 \times$ as long as wide. Head (Fig. 4C) with distinct gap between lateral edge of stemmaticum and edge of eye, lateral ocellus separated from eye by $0.25 \times$ maximum length of ocellus; temples in dorsal view curved, rounded immediately behind eye, then more linearly narrowed, measured in straight line from eye margin to lateral margin of occipital carina, c. $0.8 \times$ length of greatest eye width; in lateral view, at level of antennal sockets, gena $0.8 \times$ width of eye. Mandible strongly bent, slightly twisted, with curved groove containing long setae, from

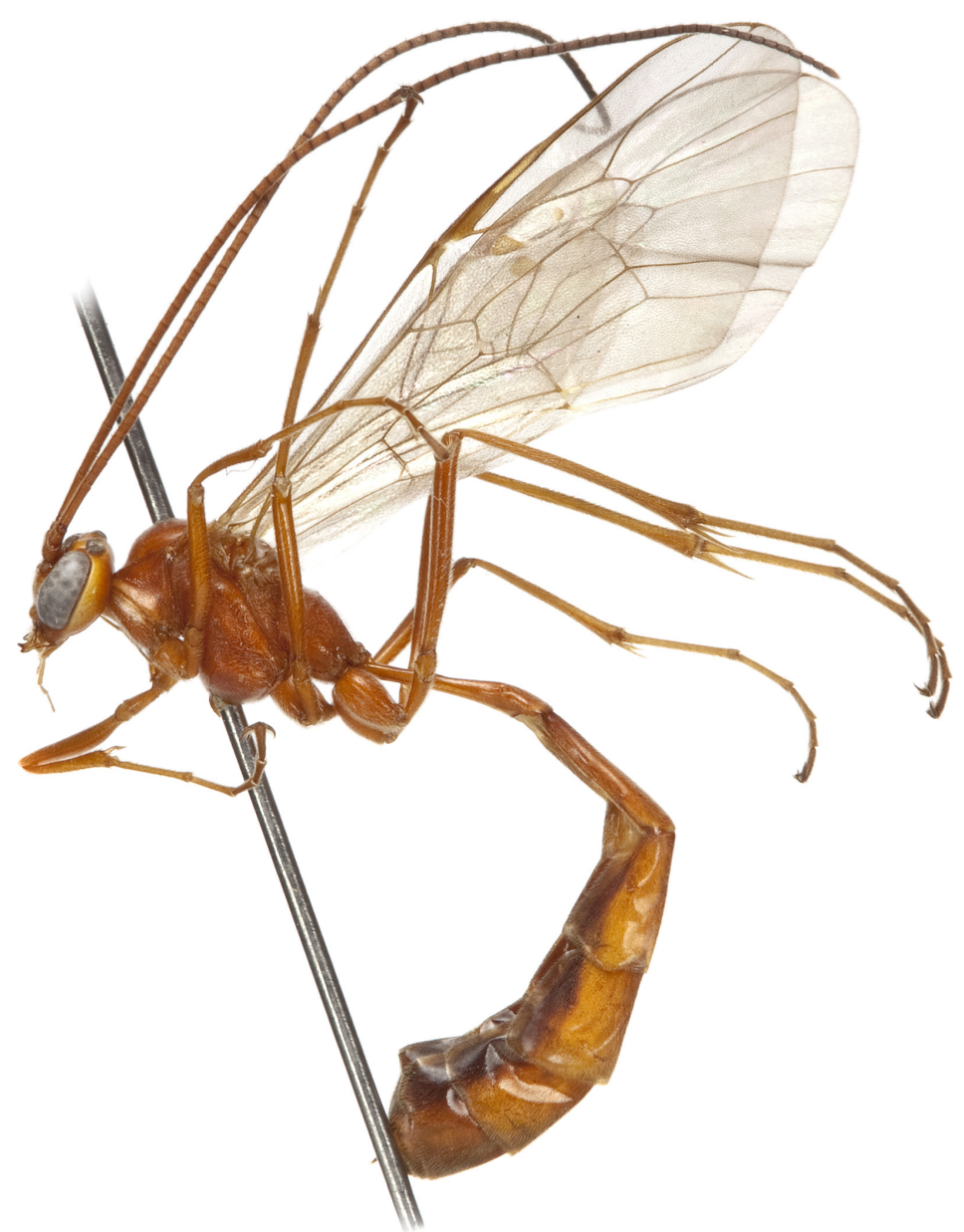

\section{| | | | | | | | | | | |}

Fig. 16. Enicospilus myricae sp. nov., habitus, paratype, $q$, Monks Wood, England, BMNH(E) 962209. Scale bar $=10 \mathrm{~mm}$. 
dorsal proximal corner to base of teeth, as in other members of E. ramidulus group; lower tooth about $0.5 \times$ length of upper. Clypeus apically truncate with wide, thin flange, very sparsely punctate. Eyes ventrally slightly convergent, face at mid-height $1.6 \times$ as wide as high, evenly, fairly closely punctate. Mesopleuron entirely, closely punctate, with faint transverse striae across dorsal portion below subalar prominence and more prominently in narrow band along dorsal 0.5 of posterior edge (deflected anteriorly by unsculptured speculum) and across wide area medio-ventrally on mesopleuron; Austrian paratype with striation reduced, only noticeable on medio-ventral area of mesopleuron. Epicnemial carina almost complete, fading out dorsally just before reaching anterior edge of mesopleuron. Mesoscutum with notauli faintly indicated anteriorly, entirely closely punctate (punctures small, closer than puncture

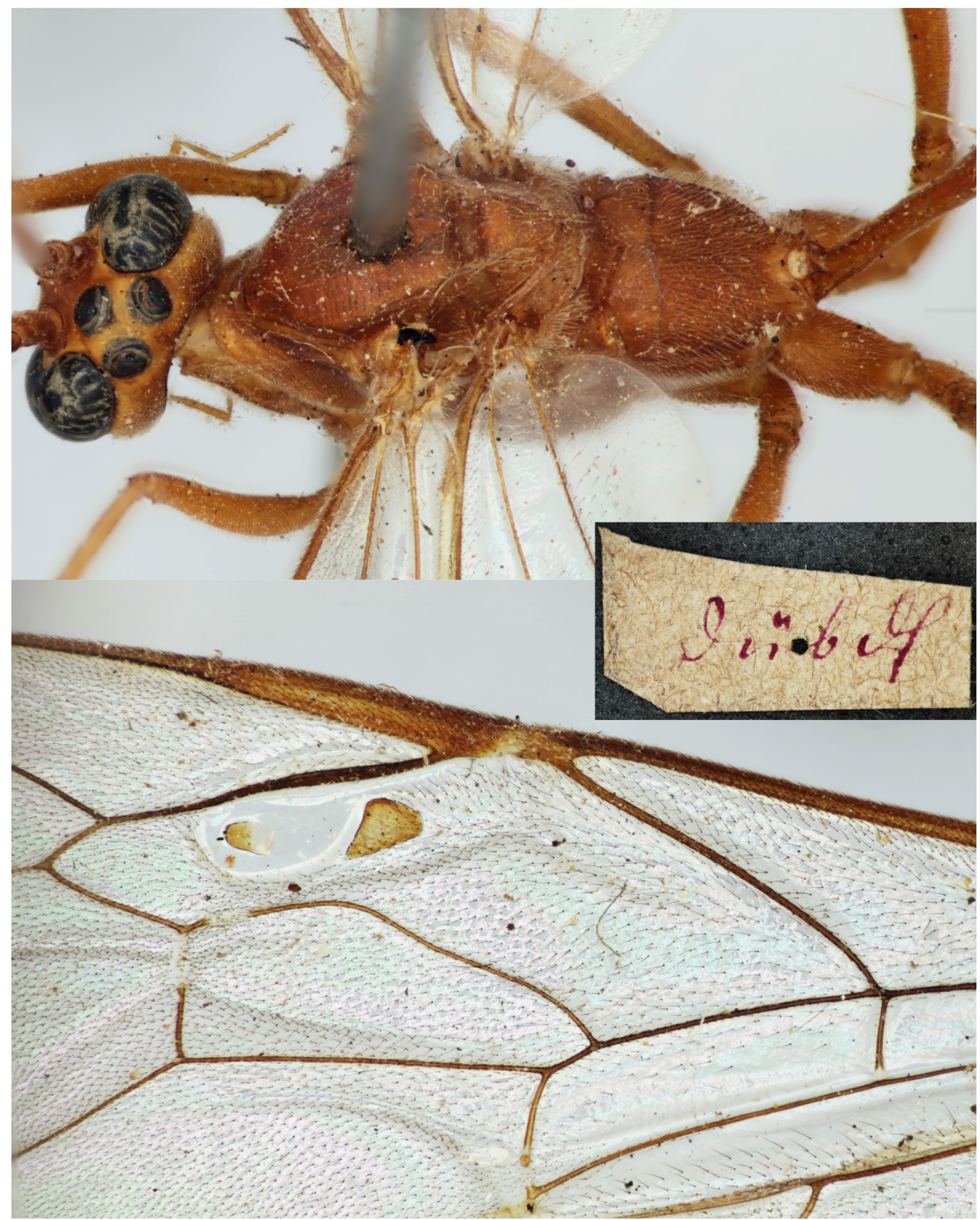

Fig. 17. Enicospilus adustus (Haller, 1885) neotype $q$. Dorsal view of head and mesosoma, fore wing discosubmarginal cell and, inset, original locality label. 
diameter), shiny. Scutellum (Fig. 5C) shiny, regularly punctate, punctures larger than on mesoscutum and further apart (larger and closer anteriorly); lateral carinae complete to near posterior end of scutellum, indicated around posterior end of scutellum as rugosity/carinulae. Fore wing (Fig. 10) as in other species of E. ramidulus group; glabrous area (fenestra) of discosubmarginal cell extending from proximal sclerite to posterior 0.3 of $R s+2 r$ (along thickened area of vein); proximal sclerite entirely pigmented, approximately triangular with rounded anterior angle, more elongate on distal corner; central sclerite roughly " $\mathrm{D}$ "-shaped, pigmented distally, fading to unpigmented, transparent proximally; distal sclerite represented by faintly pigmented line along distal-ventral margin of fenestra; fore wing vein $R s+2 r$ sinuous, uniformly widened along anterior $0.7 ; 3 r s-m 0.45 \times$ section of $M$ between $1 m-c u$ and $3 r s-m ; c u-a$ slightly to distinctly proximal to $R s \& M$. Metapleuron shiny, closely punctate. Propodeum with weakly defined central section of anterior transverse carina, anterior of this shiny and superficially punctate, posterior to this entirely reticulate-rugose or sculpture much reduced dorso-laterally. First metasomal tergite (Fig. 6C) with shallow dorsal concavity at anterior 0.45 . Second metasomal segment with laterotergite narrow, folded under; third tergite with laterotergite not demarked.

\section{Colour}

Uniformly testaceous (Fig. 16), varying from dull orange to a darker, reddish-orange (although probably dependent on preservation), except for black mandibular teeth and varying amounts of dark brown infuscation on the venter of the metasoma from 4th tergite onwards, and apical tergites at most weakly infuscate. Antenna darker apically. Generally slightly darker than E. adustus.

\section{Male}

As in female but with more antennal segments (61-64 flagellar segments; $\mathrm{n}=4)$ and striation on mesopleuron much feebler, basically absent medio-ventrally. Paramere (Fig. 8C) rather strongly narrowed posteriorly, smoothly angled into apical edge; aedeagus (Fig. 9B) with dorsal, apical area concave and laterally carinate, more rounded apically than in E. adustus (Fig. 9A) or E. cerebrator, in which apex of aedeagus less protruding dorsally and more strongly reflexed ventrally.

\section{Distribution}

Austria, England, Scotland, Wales, as detailed in the list of type material (British distribution in Fig. 18D).

Flight time (non-reared material)

June-July.

\section{Hosts}

Orthosia gracilis (Denis \& Schiffermüller, 1775) (3 specimens, from one collecting event) (Noctuidae: Hadeninae).

The majority of the few known specimens were collected in Scotland but it is a much more widespread species and it may be that it prefers boggy habitats in which few people collect ichneumonids. One paratype was collected in Monks Wood NNR, an ancient deciduous woodland with a rather rich fauna of fen or bog-associated noctuids. Unlike other British Enicospilus there is a distinct sexual dimorphism in antenna length, as males have more flagellar segments, with no overlap in the small sample size available.

Enicospilus ramidulus (Linnaeus, 1758)

Figs 2B, 11B, 18E

Ichneumon ramidulus Linnaeus, 1758: 566.

Sphex truncatus Poda, 1761: 107.

Henicospilus instabilis Kokujev, 1907: 174. 


\section{Status}

A common and widespread species, regular in light traps and rather frequently reared from Noctuidae, particularly of the subfamily Hadeninae.

\section{Material}

NMS: 53 우, $20 \hat{\delta} \hat{\sigma}, 9$ unsexed; BMNH: 80 우, $31 \hat{\jmath} \widehat{\partial}, 3$ unsexed; material from other collections:

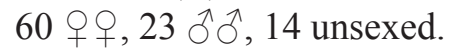

\section{Distribution (Fig. 18E)}

England: VCs 1, 2, 3, 4, 5, 6, 9, 10, 11, 13, 14, 15, 16, 17, 19, 20, 21, 22, 24, 25, 26, 27, 28, 29, 31, 36, $39,40,54,55,56,57,58,59,61,62,63,65$; Scotland: VCs 75, 84, 86, 87, 89, 90, 96, 97, 98, 99, 101, 105, 106, 110; Wales: VC 41, 45, 48, 50, 52; Ireland: H5; Channel Islands: Jersey.

Flight time (non-reared material)

June-September, with the majority in July.

\section{Hosts}

Actebia praecox (Linnaeus, 1758) (Noctuidae: Noctuinae) (1) (no collector specified; BMNH); ?Anarta myrtilli (Linnaeus, 1761) (1) (T.H. Ford) (NMS); Lacanobia oleracea (Linnaeus, 1758) (3) (P. Baker, M.R. Shaw) (NMS); Melanchra pisi (Linnaeus, 1758) (28) (P. Baker, A.E. Cockayne, A. Lord, G.T. Lyle, M.R. Shaw) (BMNH, NMS); Phlogophora meticulosa (Linnaeus, 1758) (1) (P. Baker) (NMS) (all Noctuidae, mostly Hadeninae).

Additional material in NMS: Bulgaria: Kavarna; Finland: Houtskär; France: Alpes-Maritimes, Côted'Or, Dordogne, 1 ex Panolis flammea (Denis \& Schiffermüller, 1775) (M.R. Shaw); Spain: Zaragoza, 1 ex Lacanobia oleracea (G.E. King).

\section{Remarks}

Amongst the British Enicospilus species with two discrete, pigmented fore wing sclerites, E. ramidulus is distinctive in that the mesosoma is entirely testaceous and the metasoma apically sharply black, from the 5th or 6th tergite onwards. Structurally very similar to E. adustus and E. combustus, but E. ramidulus has shorter antennae (54-60 flagellar segments, modal value 56) and colour patterns are invariable. According to published records this is a very widely distributed species; however, there are other, similar species in various parts of the world that have been misidentified as E. ramidulus.

\section{Enicospilus repentinus (Holmgren, 1860)}

Figs 2D, 11B, 13B, 19B

Ophion repentinus Holmgren, 1860: 11.

\section{Status}

New to Britain. Found in a few localities in southern England, particularly along the eastern end of the Chilterns; all specimens have been collected in the past 30 years, all but one at light. Previous records of E. repentinus in Britain (e.g., Gauld 1973) refer to E. merdarius (= tournieri). We know of no reliable host records.

\section{Material examined}

ENGLAND: 1 $\jmath^{\lambda}$, Horse Down (VC 8), 30 Jun 1984 (G.R. Else); 2 우, Tilshead (VC 8), 13 Jul. 2013 (P. Sharpe) (T. Newton coll.); 1 ㅇ, Newlands Corner (VC 17), 4 Jul. 2010 (P. Wheeler); 8 우, 1 ô, 
Aldbury (VC 20), 2, 15 Jul. 2008, 8, 20, 21 Jul. 2010, 23, 25 Jul. 2012, 1 §, 7 Jul 2013 (G.R. Broad); 1 q, 1 §̂, College Lake (VC 20), 15 Jul. 2006 (M. Albertini); 1 q, Ellesborough (VC 24), 21 Jul. 2006 (M. Albertini); 1 ㅇ, Incombe Hole (VC 24), 22 Jul. 2005 (M. Albertini) (all BMNH); 1 + Incombe Hole (VC 24), 22 Jul. 2005 (M. Albertini) (NMS); 1 , Ivinghoe Hills (VC 24), 31 Jul. 2011 (S.N. Fletcher) (S.N. Fletcher coll.); 1 ㅇ, Radnage (VC 24), 18 Jul. 2010 (A.M. George) (A.M. George coll.); 1 ㅇ, Rushbeds Wood (VC 24), 12 Jul. 2007 (M. Albertini) (M. Albertini coll.); 2 q $q$, Pitsford Water Nature Reserve (VC 32), Aug. 2012, 13 Jul. 2013 (M. Furfaro) (M. Furfaro, T. Newton colls).

\section{Additional material in NMS}

FRANCE: 1 , Hautes-Alpes, Briançon 22 Jul. 2005 (M.R. Shaw); 1 ○े, Hautes-Alpes, Col du Lautaret 6-9 Jul. 2005 (M.R. Shaw).

TURKEY: 1 ô, Ankara, Beynam 15 Jul. 1999 (M.R. Shaw).

The flight time is basically limited to July, other than one specimen collected at the very end of June and one in August.

\section{Remarks}

Smaller than E. merdarius (46-49 flagellar segments, modal value 47 in repentinus), with which it has been confused, lacking both the transparent central sclerite in the discosubmarginal cell and the elongate pigmented strip (distal sclerite) along the distal edge of the glabrous patch in the discosubmarginal cell. There are also subtle differences in the propodeal sculpture, which is less raised and shinier in E. repentinus. The two species are found in very different habitats: mainly calcareous grassland or woodland edges in the case of E. repentinus, sandy coasts in E. merdarius.

Enicospilus undulatus (Gravenhorst, 1829)

Figs 2A, 3B, 20B

Ophion undulatus Gravenhorst, 1829: 697.

Ophion arcuatus Brullé, 1846: 146.

\section{Status}

A very rarely collected species, found on southern coastal heaths where it has been reared from Lasiocampa trifolii (Denis \& Schiffermüller, 1775) (Lasiocampidae). The host is now very local and E. undulatus has not been found in Britain since 1971.

\section{Material examined}

ENGLAND: 1 ㅇ, 1 $\widehat{\text { }}$, Dungeness (VC 15), ex Lasiocampa trifolii coll. as larva 6 Jun. 1945 (G.V. Bull) (BMNH); 1 ㅇ, 1 ว , Ilfracombe (VC 4), Jul. 1971 (I.D. Gauld); 1 ㅇ, Lowestoft (VC 25), Jul. 1971 (I.D. Gauld) (latter two records taken from Gauld, 1974; specimens not in BMNH).

\section{Additional material in NMS}

SPAIN: 1 , , Zaragoza, Montes de Torrero, 230 m, 24 May 1998 (G.E. King).

\section{Remarks}

Enicospilus inflexus has been separated from E. undulatus on the basis of differences in head shape (Gauld 1974) which seem to be consistent, based on the limited material in BMNH. Although there may be a difference in host use, this is based on only two rearings of $E$. undulatus, from one place and date; although Lasiocampa trifolii is rather smaller than L. quercus, E. inflexus and E. undulatus do not differ significantly in size. 

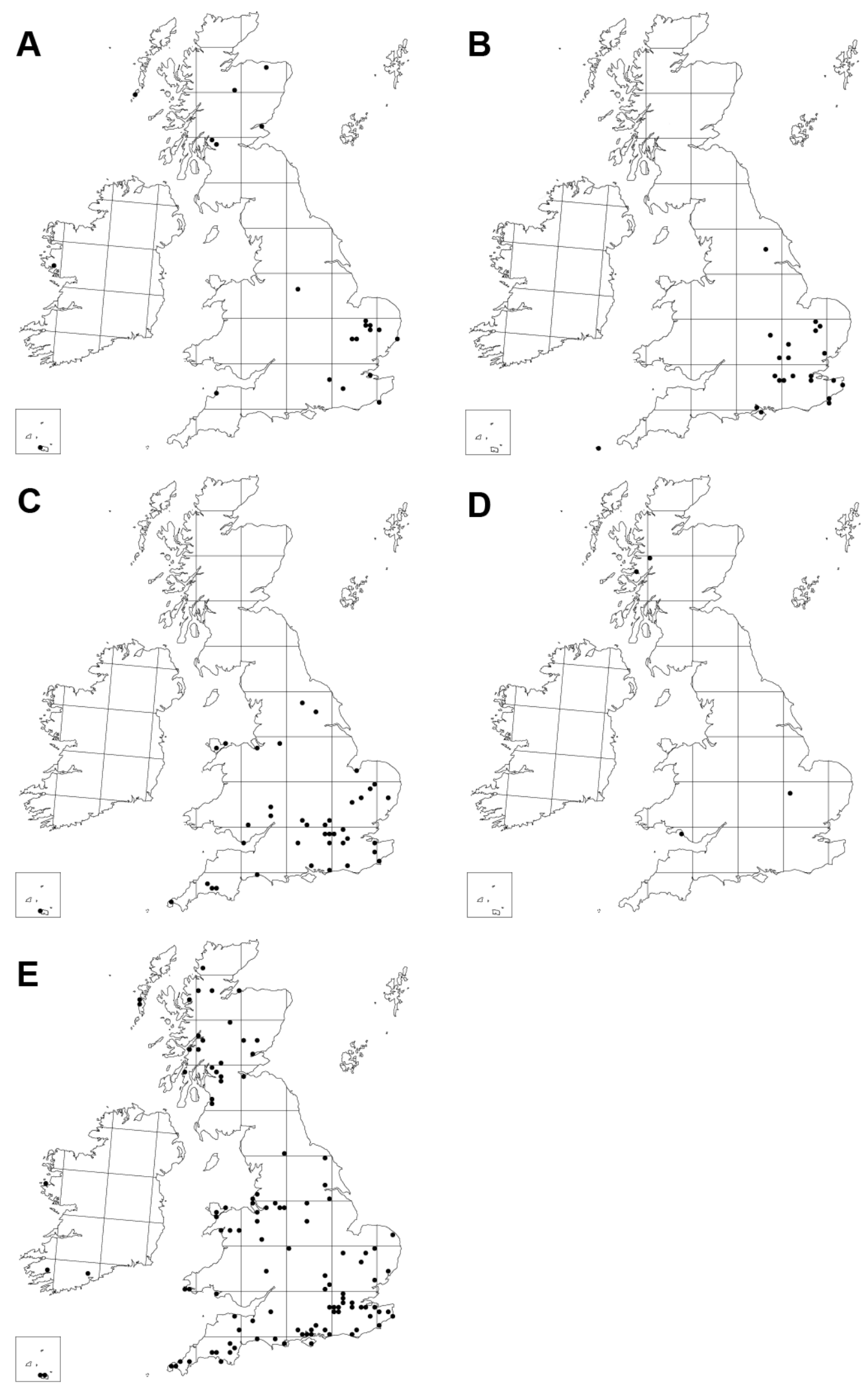

Fig. 18. Distribution maps. A. Enicospilus adustus (Haller, 1885). B. E. cerebrator Aubert, 1966. C. E. combustus (Gravenhorst, 1829). D. E. myricae sp. nov. E. E. ramidulus (Linnaeus, 1758). 

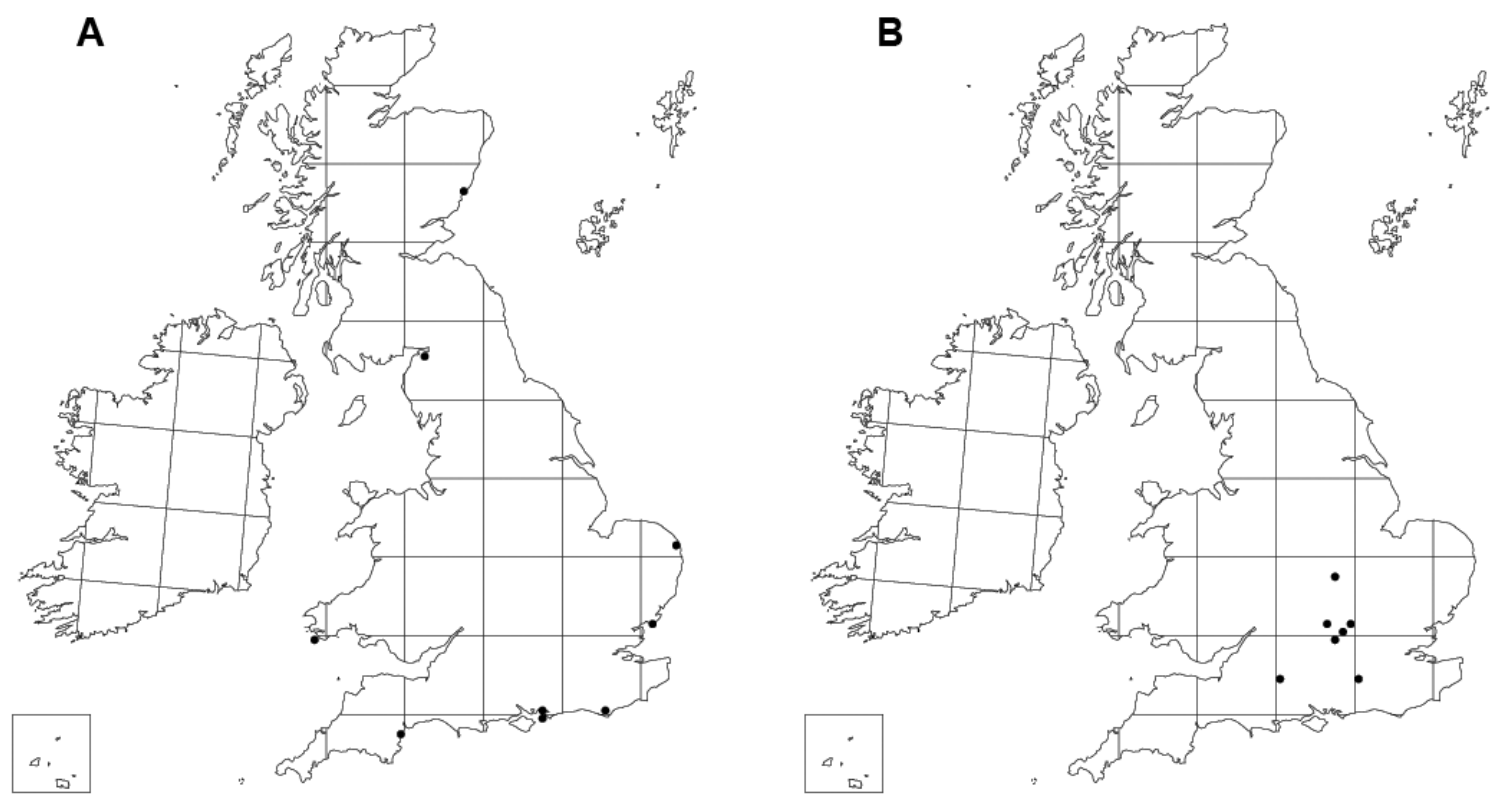

Fig. 19. Distribution maps. A. Enicospilus merdarius (Gravenhorst, 1829). B. E. repentinus (Holmgren, 1860).
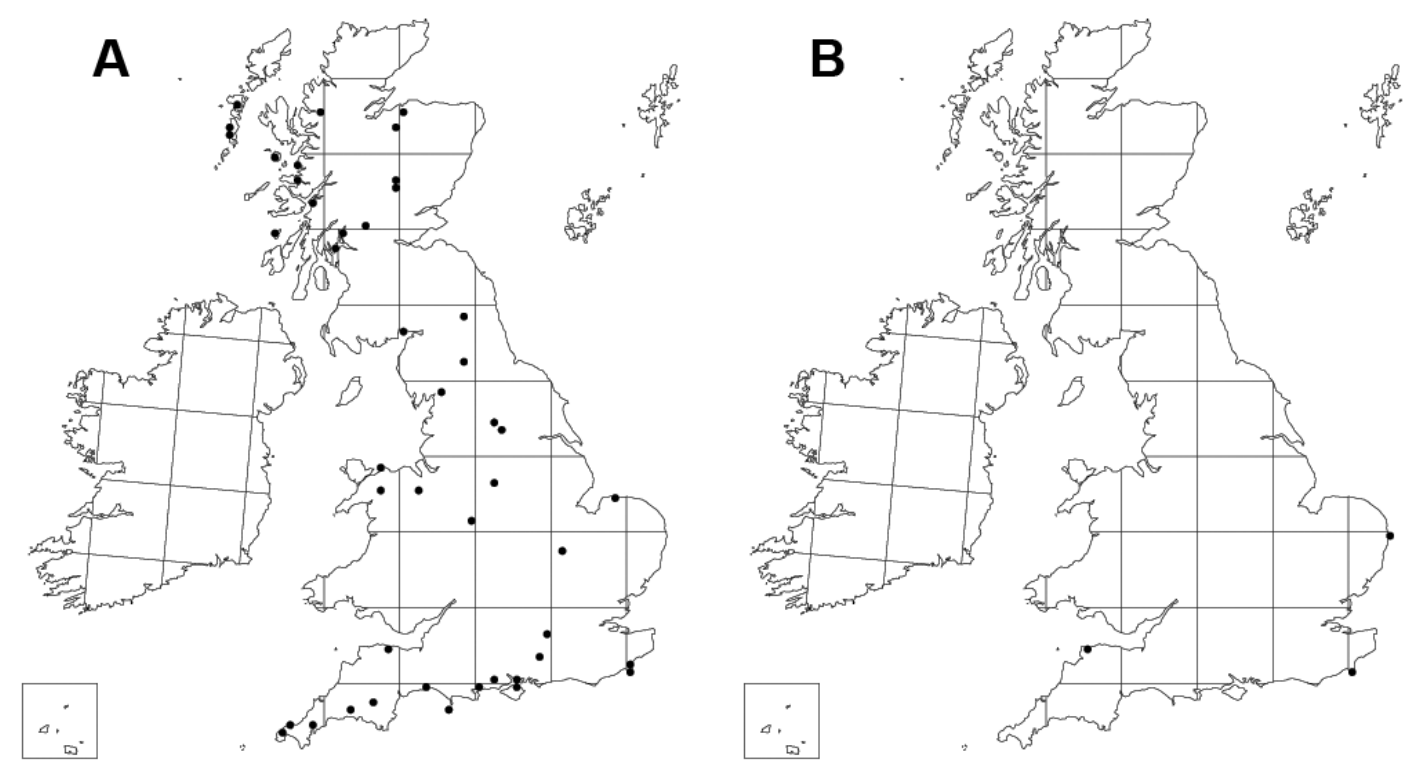

Fig. 20. Distribution maps. A. Enicospilus inflexus (Ratzeburg, 1844). B. E. undulatus (Gravenhorst, 1829). 


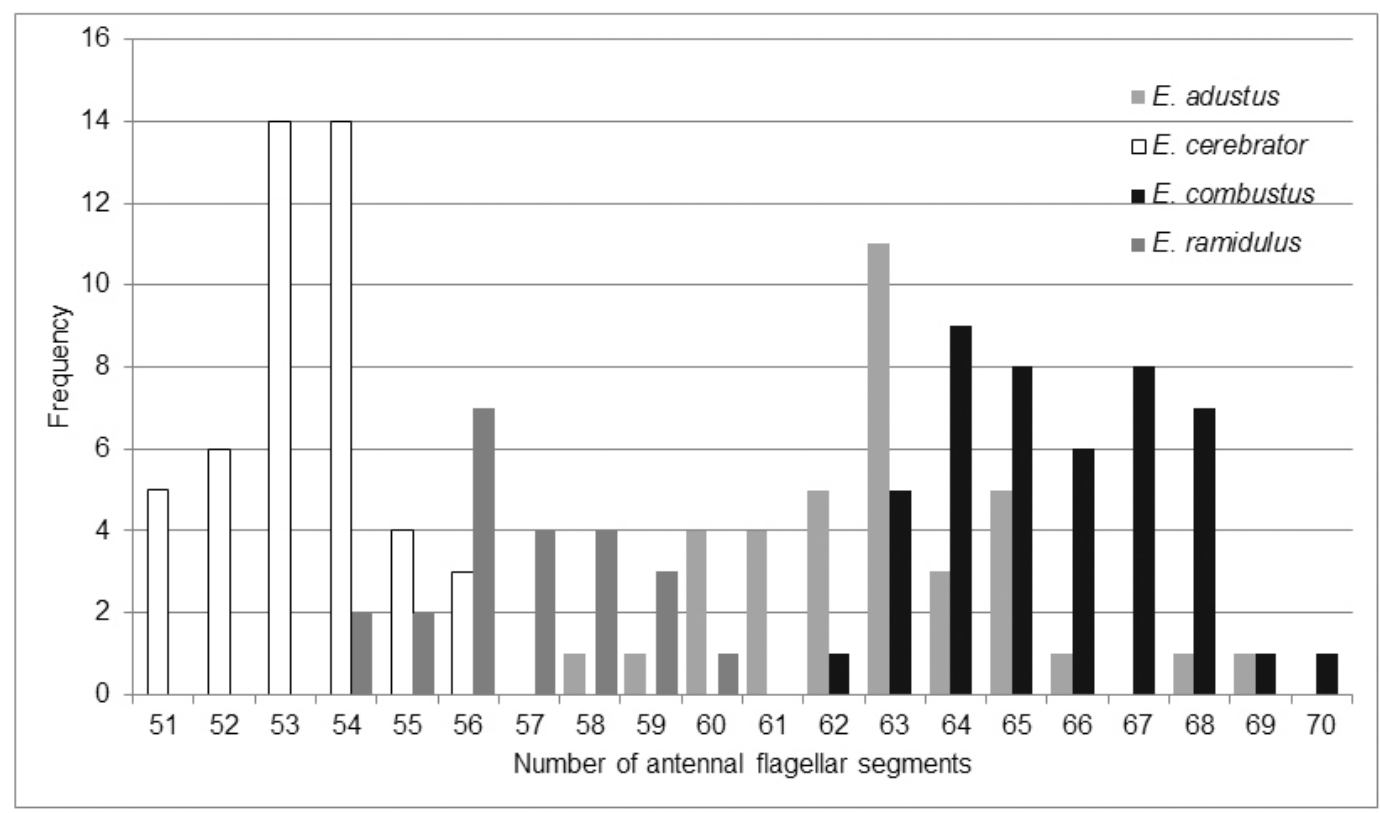

Fig. 21. Frequency distribution of number of antennal flagellar segments in four species of the Enicospilus ramidulus species-group.

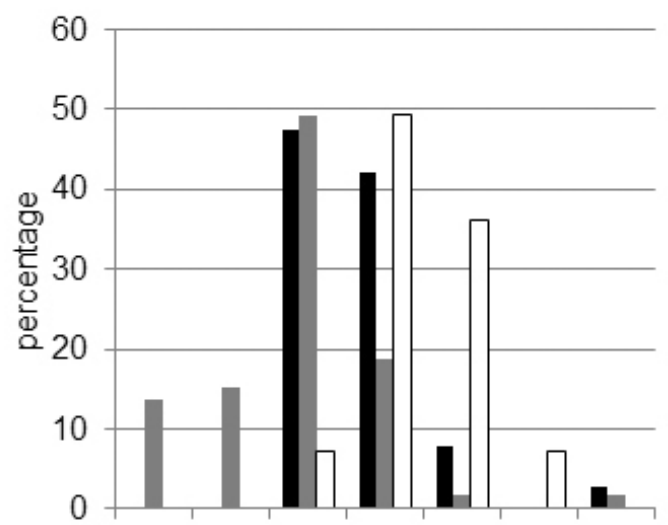

- E. adustus

E. cerebrator

$\square$ E. combustus

May June July Aug Sept Oct Nov

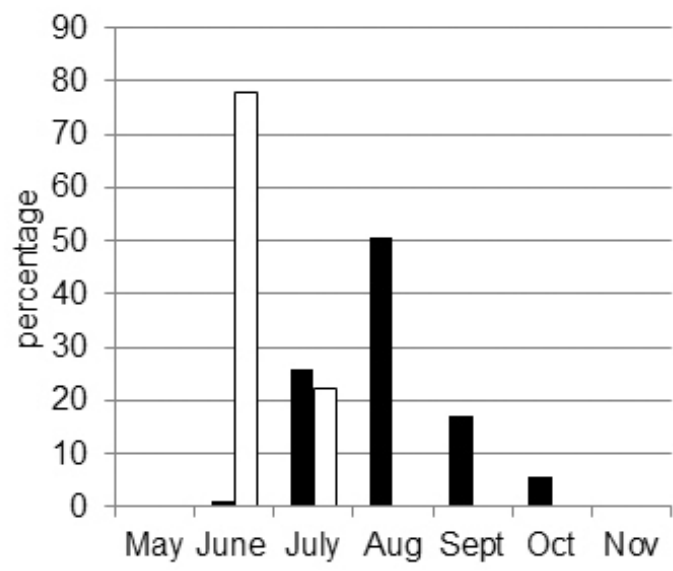

- E. ramidulus

口E. myricae

Fig. 22. Phenology of the five British species of the Enicospilus ramidulus species-group, expressed as proportions of the total, excluding reared specimens. 


\section{Discussion}

There are now five known species in Britain that are very close morphologically, which we refer to as the ramidulus complex (this is a widespread species complex with many more extralimital species, e.g., Gauld 1988). Within the ramidulus complex in Britain there is evidence of two species-pairs: E. cerebrator and E. ramidulus are smaller, with shorter antennae, fly slightly earlier in the year and have both been reared regularly from several species of Hadeninae (Noctuidae) that feed moderately high up on field layer plants; E. adustus and E. combustus are larger, with longer antennae, fly later in the season and have both been reared only very infrequently, from noctuid larvae that feed exposed, low in the vegetation; Enicospilus myricae sp. nov. may be closer to E. cerebrator and E. ramidulus, and has been reared from noctuid larvae that feed more or less exposed on more bushy vegetation. The frequency of flagellomere numbers and dates of capture (of non-reared specimens) are plotted in Figs 21 and 22. There are distinct discontinuities in flagellar segment number and no specimens with intermediate colour patterns. Enicospilus adustus and E. cerebrator have been confounded, as they both lack any distinctive markings, although they are structurally distinct. It would be very interesting to obtain DNA sequence data for these species and test our conclusions on relationships with molecular data; however, at the moment there is a distinct shortage of recently collected specimens of some species.

\section{Acknowledgements}

Anne Freitag (MZLS), James Hogan (OUMNH), Andrey Khalaim (ZIN) and Andreas Müller (ETHZ) kindly lent type material or photos of types and Andreas Müller interpreted the handwritten locality label of the E. adustus neotype. Numerous entomologists have sent specimens, mainly from their light traps, and Phil Gould (formerly of Rothamsted Research) went to great efforts to extract Ichneumonoidea from Rothamsted light trap catches. We are grateful to those who have passed on reared material. Bill Ely forwarded numerous records of Enicospilus and other nocturnal ichneumonoids from Yorkshire. William Foster (Cambridge University), Peter Chandler (BENHS), Guy Knight and Tony Hunter (WML) lent specimens and provided access to their collections. Heinz Schnee sent several German Enicospilus, including some rare rearing records.

\section{References}

Aubert J.-F. 1962. Les Ichneumonides du rivage Méditerranéen français (4e série, Alpes-maritimes). Revue Française d'Entomologie 29 (1): 124-153.

Aubert J.F. 1964. Révision des travaux concernant les Ichneumonides de France et 4e supplément au catalogue de Gaulle ( 85 espèces nouvelles pour la faune française). Bulletin de la Société Linnéenne de Lyon 33 (2): 57-65, 81-84.

Aubert J.-F. 1966. Description de dix espèces nouvelles s'ajoutant aux Ichneumonides de France et du Bassin méditerranéen. Bulletin de la Société Entomologique de Mulhouse 1966 (mai-juin): 37-46.

Brullé M.A. 1846. Tome Quatrième. Des Hyménoptères. Les Ichneumonides. In: Lepeletier de SaintFargeau A. (ed.) Histoire Naturelles des Insectes: 56-521. Librairie Encyclopédique de Roret, Paris.

Fitton M.G. 1984. Gravenhorst Ichneumonidae (Hym.) in Oxford. Entomologist's Monthly Magazine 120: $1-6$.

Fitton M.G., Graham M.W.R. de V., Bouček Z.R.J., Fergusson N.D.M., Huddleston T., Quinlan J. \& Richards O.W. 1978. Kloet and Hincks. A Check List of British Insects. Hymenoptera. Handbooks for the Identification of British Insects 11 (4), Royal Entomological Society of London, London.

Gauld I.D. 1973. Notes on the British Ophionini (Hym., Ichneumonidae) including a provisional key to species. Entomologist's Gazette 24: 55-65. 
Gauld I.D. 1974. Further notes on the British Ophionini (Hym., Ichneumonidae). Entomologist's Gazette 25: $147-148$.

Gauld I.D. 1988. A survey of the Ophioninae (Hymenoptera: Ichneumonidae) of tropical Mesoamerica with special reference to the fauna of Costa Rica. Bulletin of the British Museum (Natural History), Entomology 57: 1-309.

Gauld I.D. 1991. The Ichneumonidae of Costa Rica 1. Memoirs of the American Entomological Institute 47, American Entomological Institute, Gainesville, FL.

Gauld I.D. \& Mitchell P.A. 1978. The Taxonomy, Distribution and Host Preferences of African Parasitic Wasps of the Subfamily Ophioninae. Commonwealth Institute of Entomology, Slough, London.

Gauld I.D. \& Mitchell P.A. 1981. The Taxonomy, Distribution and Host Preferences of Indo-Papuan Parasitic Wasps of the Subfamily Ophioninae. CAB, Slough

Gravenhorst J.L.C. 1829. Ichneumonologia Europaea. Pars II. Vratislaviae.

Haller G. 1885. Entomologische Notizen. Mitteilungen der Schweizerischen Entomologischen Gesellschaft 7: 194-203. http://dx.doi.org/10.5962/bhl.part.4553

Harrington R. \& Woiwod I.P. 2007. Foresight from hindsight: the Rothamsted insect survey. Outlooks on Pest Management 18 (1): 9-14.

Hill L., Randle Z., Fox R. \& Parsons M. 2010. Provisional Atlas of the UK's Larger Moths. Butterfly Conservation, Wareham, Dorset.

Holmgren A.E. 1860. Försök till uppställning och beskrifning af de i Sverige funna Ophionider. (Monographia Ophionidum Sueciae). Kongliga Svenska Vetenskapsakademiens Handlingar 2: 1-158.

Horstmann K. 1997. Revision von Schlupfwespen-Arten (Hymenoptera: Ichneumonidae, Braconidae, Eulophidae, Torymidae). Mitteilungen der Münchner Entomologischen Gesellschaft 87: 109-119.

Izquierdo I. 1984. Los Ophioninae españoles (Hym., Ichn.). Eos 59: 45-65.

Kokujev N.R. 1907. Revue des espèces Russes du genre Henicospilus. Trudy Russkago Entomologicheskago Obshchestva 38: 161-174.

Linnaeus C. von 1758. Systema naturae per regna tria naturae, secundum classes, ordines, genera, species cum characteribus, differentiis, synonymis locis. Tomus I. Editio decima, reformata. Laurnetii Salvii, Holmiae.

Morton A. DMAP. Available from www.dmap.co.uk [accessed 27 Jan. 2016]

Poda N. 1761. Insecta musei Graecensis. J.B. Dietrich, Graecii.

Ratzeburg, J.T.C. 1844. Die Ichneumonen der Forstinsecten in forstlicher und entomologischer Beziehung. Nicolaischen Buchhandlung, Berlin.

Schwarz M. \& Shaw M.R. 1998. Western Palaearctic Cryptinae (Hymenoptera: Ichneumonidae) in the National Museums of Scotland, with nomenclatural changes, taxonomic notes, rearing records and special reference to the British check list. Part 1. Tribe Cryptini. Entomologist's Gazette 49: 101-127.

Shestakov A. 1926. Tabula diagnostica et species novae palaearcticae generis Enicospilus Stephen. Konowia 5: 25-32.

Sperring A.H. 1952. Enicospilus tournieri Fonsc. (repentinus Hlgr.) bred from larva of Agrotis ripae Hb. Transactions and Proceedings of the South London Entomological and Natural History Society 1951 (2): 19. 
Townes H.K., Momoi S. \& Townes M. 1965. A Catalogue and Reclassification of the Eastern Palearctic Ichneumonidae. Memoirs of the American Entomological Institute 5, American Entomological Institute, Gainesville, FL.

Viktorov G. A. 1957. Species of the genus Enicospilus (Hymenoptera, Ichneumonidae) Stephens in USSR. Entomologicheskoye Obozreniye 36: 179-210. [In Russian]

Vollenhoven S.C.S. van 1879. Pinacographia. Illustrations of more than 1000 species of North-WestEuropean Ichneumonidae sensu Linnaeano. Martinus Nijhoff, 'sGravenhage. http://dx.doi.org/10.5962/ bhl.title.9351

Woiwod I.P. \& Harrington R. 1994. Flying in the face of change: The Rothamsted Insect Survey. In: Leigh R.A. \& Johnston A.E. (eds) Long-term Experiments in Agricultural and Ecological Sciences: 321-342. CAB International, Wallingford.

Yu D.S., Achterberg C. van \& Horstmann K. 2012. Taxapad 2012, Ichneumonoidea 2011. Database on flash-drive. Ottawa, Ontario, Canada. Available from www.taxapad.com [accessed 27 Jan. 2016]

Manuscript received: 16 April 2015

Manuscript accepted: 3 November 2015

Published on: 4 April 2016

Topic editor: Koen Martens

Desk editor: Charlotte Thionois

Printed versions of all papers are also deposited in the libraries of the institutes that are members of the EJT consortium: Muséum national d'Histoire naturelle, Paris, France; Botanic Garden Meise, Belgium; Royal Museum for Central Africa, Tervuren, Belgium; Natural History Museum, London, United Kingdom; Royal Belgian Institute of Natural Sciences, Brussels, Belgium; Natural History Museum of Denmark, Copenhagen, Denmark. 